\title{
REVIEW
}

\section{Central regulation of food intake in fish: an evolutionary perspective}

\author{
José Luis Soengas ${ }^{1}$, José Miguel Cerdá-Reverter ${ }^{2}$ and María Jesús Delgado³ \\ 'Departamento de Bioloxía Funcional e Ciencias da Saúde, Laboratorio de Fisioloxía Animal, Facultade de Bioloxía and Centro de Investigación Mariña, \\ Universidade de Vigo, Vigo, Spain \\ 2Departamento de Fisiología de Peces y Biotecnología, Instituto de Acuicultura Torre de la Sal, Consejo Superior de Investigaciones Científicas (CSIC), \\ Castellón, Spain \\ 32Departamento de Fisiología (Fisiología Animal II), Facultad de Biología, Universidad Complutense de Madrid, Madrid, Spain
}

Correspondence should be addressed to J L Soengas: jsoengas@uvigo.es

\begin{abstract}
Evidence indicates that central regulation of food intake is well conserved along the vertebrate lineage, at least between teleost fish and mammals. However, several differences arise in the comparison between both groups. In this review, we describe similarities and differences between teleost fish and mammals on an evolutionary perspective. We focussed on the existing knowledge of specific fish features conditioning food intake, anatomical homologies and analogies between both groups as well as the main signalling pathways of neuroendocrine and metabolic nature involved in the homeostatic and hedonic central regulation of food intake.
\end{abstract}

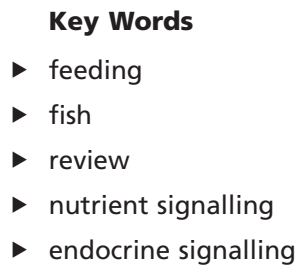

Journal of Molecular Endocrinology

(2018) 60, R171-R199

\section{Introduction}

Fish are the most diversified group of vertebrates with 33,700 species identified so far (www.fishbase.org), of which 95\% are teleosts comprising half of all known vertebrate species (Nelson 2006). Fish show a remarkable level of diversity in terms of anatomy, ecology, behaviour and genome (Wooton 1990, Gerking 1994, Volff 2004), which makes them attractive for the study of evolution of appetite-regulating systems in vertebrates (Volkoff et al. 2009).

The first teleosts appeared approx. 310 mya after evolving from the first actinopterygii approx. 400 mya. Such a long time evolution resulted in a quite heterogeneous group. To help readers non-familiar with teleost fish, a comprised phylogeny of teleosts describing main groups from available literature (Near et al. 2012, Betancur et al. 2013) is shown in Fig. 1, and this can be useful to place the different fish species for which information is available. Evidence indicates that the regulation of food intake is well conserved along the vertebrate lineage, at least between teleosts and mammals (Volkoff 2016, Delgado et al. 2017). However, several differences arise in the comparison between both groups. In the following sections, we aimed to describe them from an evolutionary perspective. Readers interested in a detailed description of mechanisms are redirected to recent reviews on these topics (Volkoff 2016, Delgado et al. 2017, Ronnestad et al. 2017, van de Pol et al. 2017).

\section{Specific features conditioning food intake in fish}

Even in the mechanisms comparable between fish and mammals, the specific responses obtained are not 

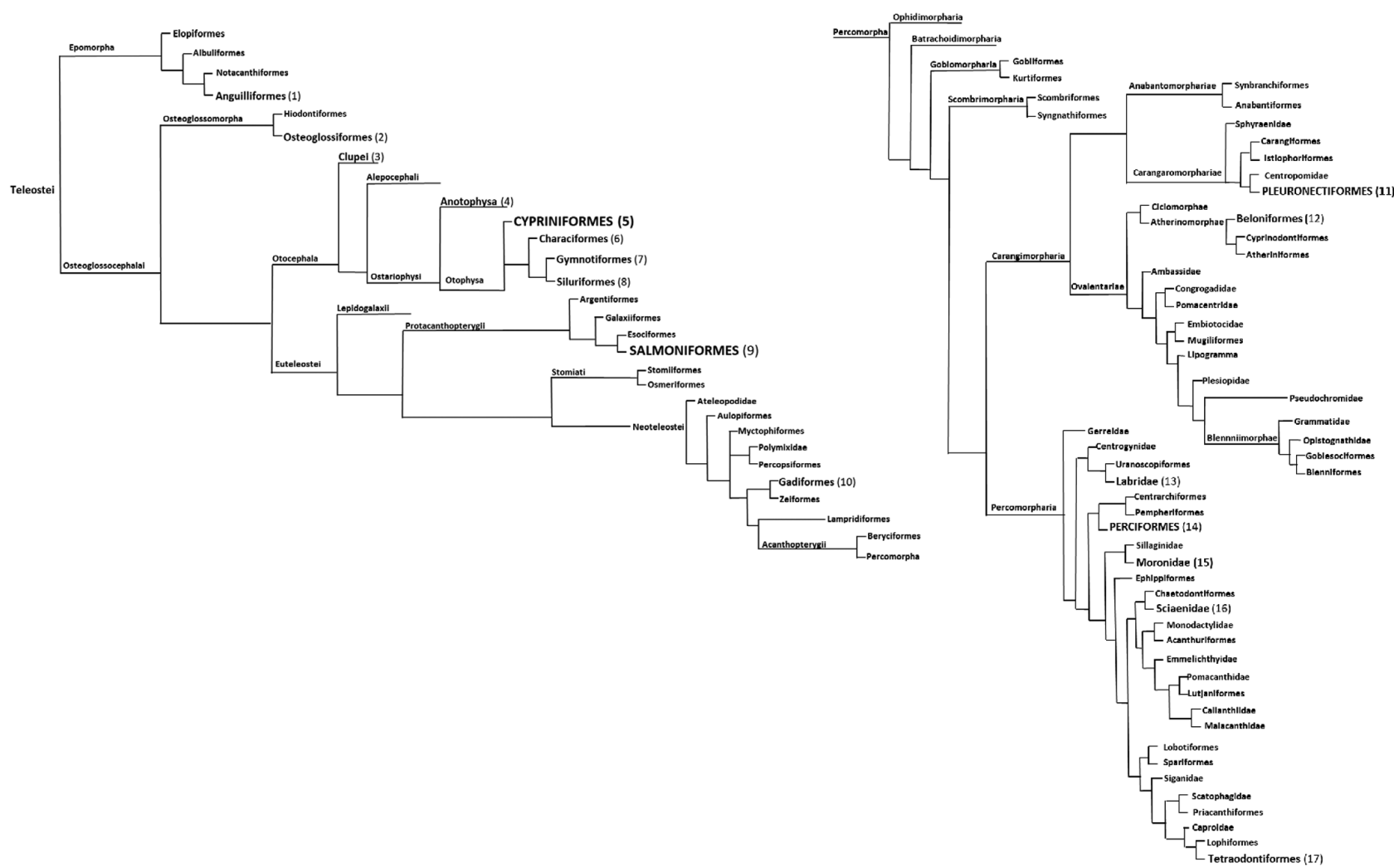

Figure 1

Schematic overview showing phylogeny of the infraclass teleostei (teleost fish) based on Near et al. (2012) with Percomorpha described in detail on the right. The species studied so far on any aspect of food intake regulation (see Volkoff 2016, Delgado et al. 2017, Ronnestad et al. 2017, van de Pol et al. 2017) belong to the groups denoted with a pathenthesis as follows. (1) Anguilliformes: Japanese eel (Anguilla japonica). (2) Osteoglossiformes: Elephant fish (Callorhinchus milii). (3) Clupei: Tapertal anchovy (Colia nasus). (4) Anatophysa: milkfish (Chanos chanos). (5) Cypriniformes: common carp (Cyprinus carpio), goldfish (Carassius auratus), ya fish (Schizothorax prenanti), zebrafish (Danio rerio), grass carp (Ctenopharyngodon idellus), blunt snout bream (Megalobrama ambycephalus), tench (Tinca tinca), bunnei (Barbus sharpeyi), gibel carp (Carassius auratus gibelio) topmouth culter (Culter alburnus). (6) Characiformes: blind cavefish (Astynnax mexicanus), red-bellied piranha (Pygocentrus natterei), dourado (Salminus brasilensis), pacu (Piaractus mesopotamicus), pirapitinga (Piaractus brachypomus), black tetra (Gymnocoimbus ternetzi). (7) Gymnotiformes: electric fish (Eigenmannia viescens). (8) Siluriformes: African sharptoothcatfish (Clarias gariepinus), walking catfish (Clarias batrachus), channel catfish (Ictalurus punctatus), yellow catfish (Palteobagrus fulvidraco). (9) Salmoniformes: Atlantic salmon (Salmo salar), Arctic charr (Salvelinus alpinus), coho salmon (Oncorhynchus kisutch), rainbow trout (Oncorhynchus mykiss), brown trout (Salmo trutta), chinook salmon (Oncorhynchus tshawytscha). (10) Gadiformes: Atlantic cod (Gadus morhua), burbot (Lota lota). (11) Pleuronectiformes: Atlantic halibut (Hippoglossus hippoglossus), winter flounder (Pseudopleuronectes americanus), sole (Solea solea), Senegalese sole (Solea senegalensis), olive flounder (Paralichthys olivaceus), turbot (Scophthalmus maximus), barfin flounder (Vernoper moseri), starry flounder (Platichthys stellatus), Brazilian flounder (Paralichthys orbignyanus). (12) Beloniformes: medaka (Oryzias latipes). (13) Labridae: Cunner (Tautogolabrus adspersus), ornate wrasse (Thalassona pavo), orange-spotted grouper (Epinephelus coioides). (14) Perciformes: gilthead sea bream (Sparus aurata), tilapia (Oreochromis mossambicus), nile tilapia (Oreochromis niloticus), pacific bluefin tuna (Thunus orientalis), golden pampano (Trachinotus blochii), green sunfish (Lepomis cyanellus), mandarin fish (Siniperca chuatsi), Murray cod (Maccullochella peeli), mackerel (Scomber japonicas), yellowtail (Seriola quinqueradiata), cobia (Rachycentron canadum), mudskipper (Periophthalmus modestus), white sea bream (Diplodus sargus), bluegill (Lepomis machrochirus). (15) Moronidae: sea bass (Dicentrarchus labrax), striped bass (Morone saxatilis). (16) Scianeidae: yellow croaker (Larimichthys crocea), red drum (Sciaenops ocellatus). (17) Tetraodontiformes: tiger puffer (Takifugu rubripes).

identical. In some cases, these differences relate to the limited available studies in fish. In most cases, however, the large number of fish species, habitats, feeding habits and gastrointestinal tract (GIT) anatomy and physiology, as well as a number of intrinsic and extrinsic factors affecting feeding behaviour and physiology result in clear fish-specific features (Hoskins \& Volkoff 2012).

Anatomical differences between mammals and fish include brain and GIT morphologies as well as the existence in fishes of specific organs not present in mammals (urophysis and Stannius corpuscles for instance) (Volkoff et al. 2009). Anatomical and functional differences occur within fish species. For instance, fishes feeding habits range from herbivore to carnivore, and this results in a wide variety of GIT morphology and hormone profiles (Olsson 2011). Carnivores and omnivores have stomach, pyloric caeca and relatively short and straight intestines, whereas herbivores and detritivores may lack 
both stomach and caeca and have long intestines (Leknes 2015). Different diets and GIT also translate into different digestive enzyme profiles and different methods of nutrient storage (Day et al. 2011).

Fishes do not expend energy to maintain a constant body temperature and require less energy for the excretion of waste nitrogenous products resulting in lower metabolic rates (van de Pol et al. 2017). The growth of many fish species is indeterminate (Volkoff et al. 2009) in contrast with the finite growth in mammals. Fish experience periods of food deprivation much more frequently and with more duration than mammals due to seasonal changes, reproduction or aquaculture practices (Ronnestad et al. 2017), and metabolism is adapted to those changes (Navarro \& Gutiérrez 1995). Furthermore, many fish species, including several of the best known models, are carnivores, which is in contrast with the mammalian models studied so far (almost all of them omnivores/herbivores). Accordingly, several of the differences in food intake regulation might relate to the higher metabolic importance in fish of protein and lipids compared with carbohydrates (Polakof et al. 2012).

Major differences in the structure and function of appetite-related hormones exist between mammals and fish. For example, sequences were highly conserved for neuropeptide Y (NPY) but not for leptin (Hoskins \& Volkoff 2012). Furthermore, fish experienced an extra round of genome duplication compared with mammals (Meyer \& van de Peer 2005) resulting in multiple isoforms of neuropeptides, carriers, receptors, enzymes, etc. Accordingly, different functions may be attributed to different isoforms in fish compared with mammals (Volkoff 2016). This is further complicated in some of the most studied groups of fish, such as cyprinids and salmonids, which underwent an additional round of genome duplication (Pasquier et al. 2016).

Feeding behaviour is highly influenced by environmental factors including temperature, hypoxia, light regime and wavelength, photoperiod or salinity among others (Volkoff et al. 2010, van de Pol et al. 2017). Furthermore, some of these factors change in a rhythmic fashion, and this affects feeding directly through seasonal and circadian rhythms (Kulczykowska \& Sánchez-Vázquez 2010) or indirectly through rhythms in endocrine systems (Cowan et al. 2017, Isorna et al. 2017). Stocking density directly influences fish feeding, and this is extremely important in aquaculture (Boujard et al. 2002, Paspatis et al. 2003). Several fish species have an aggressive behaviour resulting in the presence of dominant and subordinate individuals displaying important differences in feeding behaviour between them (Ronnestad et al 2017).

Finally, it is important to mention a methodological issue when comparing food intake measurements in fish vs those carried out in mammals. In mammals, food intake is usually measured under demand with animal having access to food ad libitum. In contrast, in most available studies in teleosts a pre-weighed amount of food is provided to the ambient water and after a period of time is removed and weighed, which cannot be considered truly demand-feeding since access to feed is time limited. Only those studies where fish operate a demand-feeding system (Geurden et al. 2007, Rubio et al. 2008, Leal et al. 2009, 2011, 2013, Attia et al. 2012, Klaren et al. 2013) are strictly comparable to those carried out in mammals.

\section{Fish brain regions involved in food intake regulation: analogies and homologies}

Neuronal circuits controlling survival-orientated behaviors, like feeding, are under selective pressure and finely regulated by a central circuitry that guarantees functional viability of the system. These neuronal circuits exhibit a high degree of redundancy ensuring the regulation of peripheral energy demands and animal survival. This entails certain experimental difficulties because of the compensatory responses of the neuronal circuits regulating food intake.

This selective pressure suggests an evolutionary conservation of mechanisms and neuronal pathways involved in the regulation of food intake. Unfortunately, the topology of the actinopterygian brain differs from that of non-actinopterygian vertebrates because of the differences in the embryonic development. During the first steps of development, in most vertebrates, the telencephalon develops through the process of evagination that involves the protrusion and expansion of the lumen of neural tube to form the telencephalic ventricles. In rayfinned fish, the roof of the neural tube extends laterally so that the paired dorsal regions move lateroventrally in the so-called process of eversion (Fig. 2). Such disparity leads to errors when making topographical comparisons and makes it difficult to find homologies between the brain structures of ray-finned fish and other vertebrates. As a result, a specific nomenclature was proposed (Nieuwenhuys 1959, Northcutt \& Davis 1983) and putative homologous areas must fulfil three key criteria (Mueller \& Wullimann 2009), such as (i) embryonic topology, (ii) developmental history (shared expression patterns of regulatory genes) and (iii) neuronal phenotype in adults. 
A
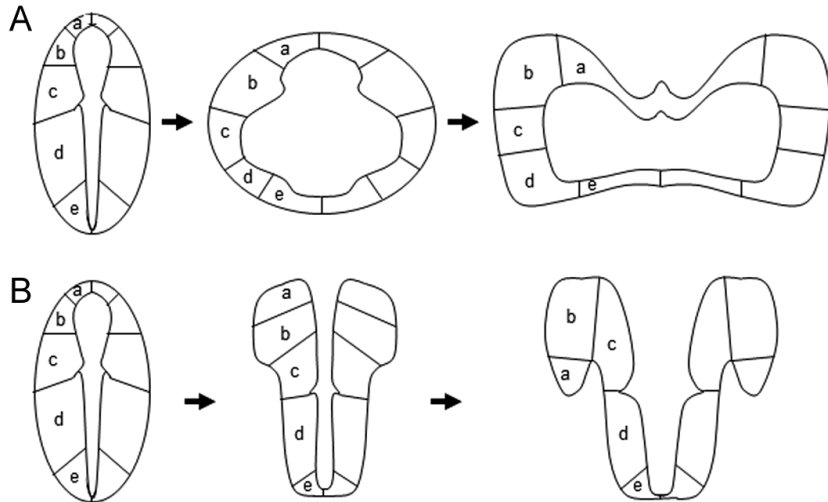

Figure 2

(A) Process of evagination in the forebrain of most vertebrates during early development. (B) Process of eversion in the forebrain of ray-finned fish. Comparison of the position of lower case letters makes for easy comparisons between evagination and eversion processes. Modified from Cerdá-Reverter and Canosa (2009).

Additional information on connectivity patterns and/or physiological function can support developmental and molecular data but not refute them since homology should not be dependent on function (Mueller \& Wullimann 2009). Therefore, the search of homologies has focussed mainly on forebrain and particularly telencephalic areas because of topological challenges (Wulliman \& Mueller 2004, Mueller \& Wullimann 2009, Goodson \& Kingsbury 2013). The dorsal and ventral regions (Dld +Dlv) of the medial pallium (Mueller 2012) comprise the homologue region of the hippocampal formation (Ganz et al. 2014) that is essential for spatial cognition and memory (Rodríguez et al. 2002). The ventral pallium (VM, Mueller 2011) or medial region of the dorsal telencephalon (Dm) contains the homologue of the pallial amygdala that plays an important role in emotional behaviours (Ganz et al. 2014). Targeted lesions of Dm disrupt aggressive, reproductive and parental behaviour, whereas electrical stimulation induces arousal and escape/defensive responses (Salas et al. 2006). In addition, lesions of Dm impair the retention of avoidance behaviour in goldfish (Portavella et al. 2004). More caudally, the posterior area of the dorsal telencephalon (Dp) contains a high number of olfactory projections resembling the lateral pallium of other vertebrates or piriform cortex in mammals (Mueller $\&$ Wullimann 2009). At the subpallial level, the dorsal part of the ventral telencephalon $(\mathrm{Vd})$ together with the central region (Vc) seem to be homologue of the basal ganglia, whereas the ventral part of the ventral telencephalon (Vv) contains the homologue of the septum (Mueller \& Wullimann 2009, Ganz et al. 2012, Bshary et al. 2014). At the postcommissural level, the supracommissural (Vs) and postcommissural $(\mathrm{Vp})$ parts of the ventral telencephalon contain the homologue of subpallial amygdala (Biechl et al. 2017) and the bed nucleus of the stria medullaris (BNSM) is placed ventrolateratelly in close proximity to the lateral forebrain bundle at the level of posterior commissure (Mueller \& Guo 2009). Furthermore, recent studies (Biechl et al. 2017) identified a new area in the caudal region of the ventral telencephalon in fish called the intermediate nucleus of the ventral telencephalon (Vi), homologue of the medial amygdala and involved in the odour recognition in zebrafish.

In mammals, the pallial and subpallial structures host reward systems that potentiate or reduce the motivation to eat. Dopaminergic projections from ventral tegmental area (VTA) to the nucleus accumbens (NAc) in the ventral striatum, hippocampus, amygdala and cortex prefrontal as well as projections form substantia nigra ( $\mathrm{SN}$ ) to the dorsal striatum/caudoputamen $(\mathrm{CPu})$ promote rewardrelated activities and are essential for feeding (Szczypka et al. 1999, 2001). Dopamine release emphasizes relevant environmental information but suppresses minor signals focusing the attention of the animal on significant stimuli. Food or its indicators increase firing rate in dopamine neurons converging the attention of the animals on food cues (Palmiter 2007). In the absence of dopamine, most stimuli are overlooked and animals become hypoactive, apathetic and aphagic and die because of starvation (Zhou \& Palmiter 1995). Starvation in dopamine-deficient mice relates to the lack of pleasure associated with eating (anhedonia, Palmiter 2007). Dopamine signalling rescue in the dorsal striatum (caudoputamen) but not in the ventral striatum (nucleus accumbens) restores feeding levels in dopamine-deficient mice despite both areas being involved in restoring the preference for palatable diets (Szczypka et al. 2001). Subsequent studies demonstrated that rescue of dopamine production in the SN pars compacta also restored feeding levels and food preference in dopaminedeficient mice thus highlighting the importance of the $\mathrm{SN}-\mathrm{CPu}$ pathway in the motivational regulation of feeding behaviour (Hnasko et al. 2006). Although the ascending dopaminergic subsystems to the striatum (mesostriatal mesolimbic and mesocortical) have been tentatively identified in teleosts (Rink \& Wullimann 2001, 2002), no studies regarding goal-directed feeding behaviour have been reported. The periventricular nucleus of posterior tuberculum (Tpp) might be homologous to VTA, whereas the nucleus of the posterior tubercle (NPT) seems to be the SNc homologue (Meredith \& Smeets 1987).

The hypothalamus is a critical region involved in homeostatic regulation of energy balance in vertebrates 
(Berthoud 2002) but highly variable among anamniota, and again, it is difficult to homologize many of the nuclei across gnathostomes (Norhcutt 1995). Studies focusing on homology of hypothalamic areas controlling energy balance in fish are scarce and weakly inferred according to neuronal phenotype, connectivity patterns and/or lesion studies. The hypothalamic inferior lobe, particularly areas closed to the hypothalamic lateral recess, as well as the ventro-posterior hypothalamus, are involved in the control of food intake (Demski \& Knigge 1971). The latter areas form a hypothalamic centre in which food intake is modified according to visceral and sensorial incoming information (Demski 2012). The hypothalamic inferior lobes form a prominent paired structure on the ventral side of the teleostean brain that seems to be an apomorphic structure with no equivalent in mammalian brain (Northcutt 1995). Electrical stimulation in the region surrounding the hypothalamic lateral recess of the inferior lobe induces a feeding and aggressive response in bluegill (Lepomis machrochirus; Demski \& Knigge 1971). The inferior lobe is integrated within the topology of the gustatory, visual and auditory systems of the goldfish brain and is thought to be a multisensory integration centre (Rink \& Wulliman 1998). Therefore, the inferior lobe likely plays an important role integrating sensory information and possibly releasing an orchestrated feeding response.

The periventricular region of the fish tuberal hypothalamus is filled by neurons of the lateral tuberal nucleus $(\mathrm{NLTd}+\mathrm{NLTv})$ or dorsal hypothalamus $(\mathrm{Hd}+\mathrm{Hv})$ (Wullimann et al. 1996). Phenotypic and connectivity data suggest that the NLTv is the teleostean homologue of the mammalian arcuate nucleus (ARC) (Cerdá-Reverter et al. 2000a,b, 2003a), a key area for the control of food intake in mammalian species (Waterson \& Horvath 2015). ARC neurons are the only neurons producing agoutirelated peptide (AgRP) in mice brain (Bangol et al. 1999) thus providing an excellent deterministic clue of the ARC. Many of the AgRP neurons in the ARC are GABAergic (Horvath et al. 1997), coexpress NPY (Hahn et al. 1998) and regulate the activity of the cocaine and amphetaminerelated transcript (CART)/pro-opio melanoncortin (POMC) neurons in the ARC (Cowley et al. 2001). Ventral neurons of the NLT/H are the only neurons synthesizing AgRP in fish brain and respond to fasting by increasing AgRP mRNA abundance (Cerdá-Reverter \& Peter 2003, Agulleiro et al. 2014). Although there are no available studies on NPY/AgRP colocalization in fish yet, NLTv neurons in sea bass produce NPY (Cerdá-Reverter et al. 2000a,b), thus providing phenotypical evidence of the NLTV/ARC homology. This phenotypical/functional homology is supported by the production of the central melanocortin peptides. In rodents, POMC is exclusively expressed in the ARC and the nucleus of the tractus solitarius (NTS) of the brainstem (Bangol et al. 1999). Studies in fish demonstrated that POMC is also expressed in the completely rostro-caudal extension of the NLT reaching the caudal tuberal hypothalamus of several species (CerdáReverter et al. 2003b), but no expression was found in the vagal lobe (VLo), the fish homologue of the NTS (Yáñez et al. 2017). In rodents, the POMC/CART neurons are activated by leptin (Elias et al. 1989). Again, there are no studies showing CART/POMC colocalization in fish but CART peptides are found in fish NLT (Akash et al. 2014). Intrahypothalamic ARC projections constitute an intricate hypothalamic network for the control of a variety of homeostatic processes including central regulation of energy balance. ARC provides inputs to nearly the entire periventricular zone of the hypothalamus including the ventral $(\mathrm{VMH})$ and dorsal medial nucleus $(\mathrm{DMH})$, the paraventricular nucleus $(\mathrm{PVN})$, the lateral $(\mathrm{LH})$ and the perifornical hypothalamus ( $\mathrm{PH}$ ) (Bouret et al. 2004). The projection $\mathrm{ARC} / \mathrm{PVN}$ is critical for the control of energy since physical disruption of ARC/PVN connections results in increased food intake and obesity (Bell et al. 2000). The AgRP/NPY neurons provide innervation to the PVN where the melanocortin 4 receptor (MC4R) is constitutively activated (Ghamari-Langroudi et al. 2011). In fish, POMC and AgRP neurons profusely project to the anterior part (PPa) and magnocellular subdivision of the preoptic area (POA) in zebrafish (Forlano \& Cone 2007) and sea bass (Agulleiro et al. 2014). In addition, MC4R is also abundantly expressed in the POA of goldfish and sea bass (Cerdá-Reverter et al. 2003a,b, Sánchez et al. 2009). The arrangement of transcription factor domains has allowed the precise delineation of POA in the zebrafish larval brain showing that the dorsal region or PM features typical neurosecretory cell types known to be located in the mammalian PVN. Therefore, phenotype, hodological and topographical data allow us to suggest that dorsal half POA is the homologous region of mammalian PVN, whereas the posterior region (PPp) might be the homologue of the supraoptic nucleus (Herget et al. 2014, Herget \& Ryu 2015).

Figure 3 displays the main telencephalic and hypothalamic regions of a typical mammal (mouse) and telelost fish (sea bass). 


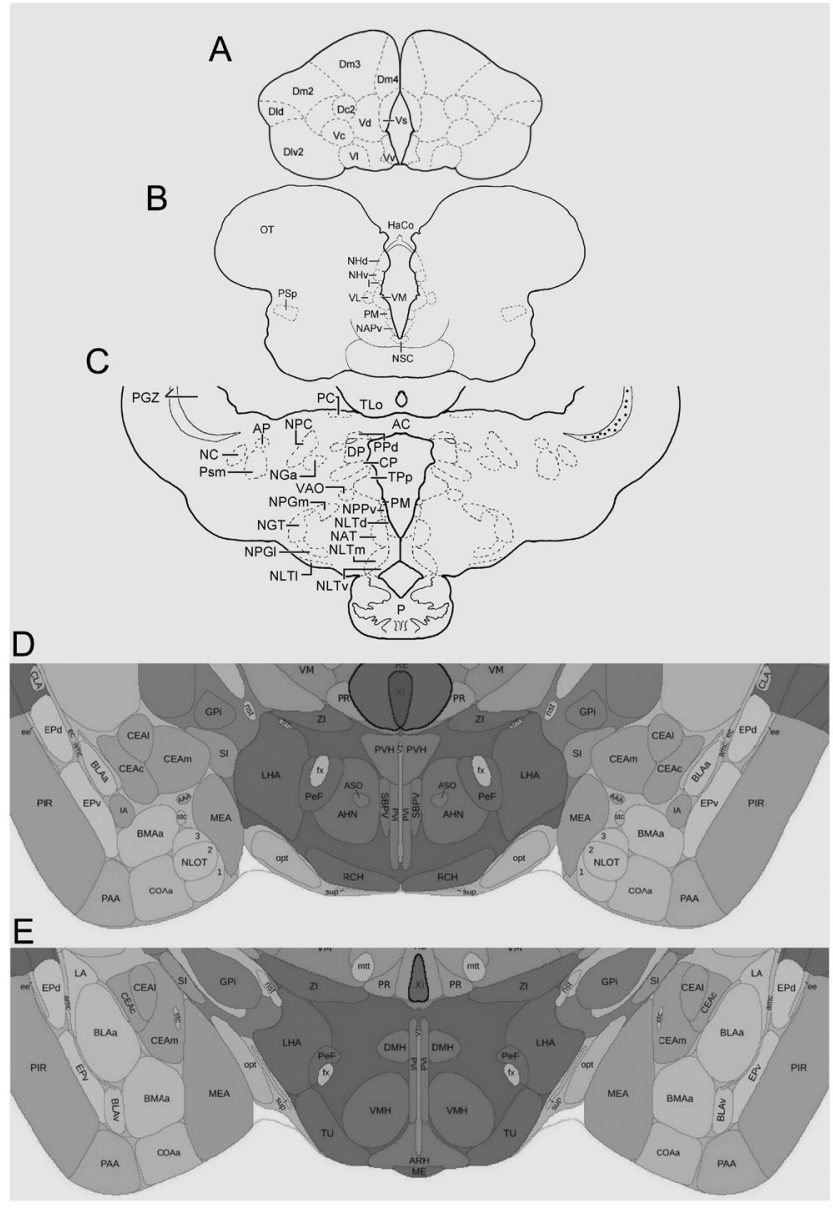

Figure 3

Schematic overview showing telencephalic and hypothalamic brain regions of seabass ( $A, B$ and $C$ ) and mouse ( $D$ and $E$ ) brain. ( $A$ ) Sea bass rostral telencephalon showing homologue areas of the mammalian amygdala. (B) Preoptic region of the sea bass brain containing the magnocellular subdivision of the preoptic area (PM) homologue to the mouse PVH/PVN (D). (C) Hypothalamic region of the seabass brain showing the localization of the ventral subdivision of the lateral tuberal nucleus (NLTV) homologue to the mammalian arcuate nucleus. Mouse brain charts were obtained from interactive Allen's brain atlas (http:// www.brain-map.org/overview/index.html). Sea bass charts were modified from Cerdá-Reverter et al. $(2000 a, b)$. AC, anterior commissure; AHN, anterior hypothalamic nucleus; Amc, amygdalar capsule; $A P$, accessory pretectal nucleus; ARH, arcuate nucleus; ASO, accesory supraoptic group; BLAa, basolateral amygdalar nucleus, anterior part; BLAv, basolateral amygdalar nucleus, ventral part; BMAa, basomedial amygdalar nucleus, anterior part; CEAc, central amygdalar nucleus, central part; CEAl, central amygdalar nucleus, lateral part; CEAm, central amygdalar nucleus, medial part; CLA, claustrum; COAa, cortical amygdalar area, anterior part; $\mathrm{CP}$, ventral posterior thalamic nucleus; CPu, caudoputamen; Dc2, subdivision 2 of the central part of the dorsal telencephalon; DId, laterodorsal part of the dorsal telencephalon; Dlv2, subdivision 2 of the lateroventral part of the dorsal telencephalon; Dm2, Subdivision 2 of the medial part of the dorsal telencephalon; Dm3, subdivision 3 of the medial part of the dorsal telencephalon; Dm4, subdivision 4 of the medial part of the dorsal telencephalon; DMH, dorsomedial nucleus of the hypothalamus; DP, dorsal posterior thalamic nucleus; EPd, endopiriform nucleus, dorsal part; $\mathrm{EPV}$, endopiriform nucleus, ventral part; $\mathrm{fx}$, columns of the fornix; GPi, globus pallidus, internal segment; $\mathrm{HaCo}$, habenular commissure; $\mathrm{Hv}$,

\section{Neuroendocrine signalling}

\section{Homeostatic regulation}

Multiple neuroendocrine systems have evolved to ensure a homeostatic energy supply in vertebrates. In fact, during the last three decades, a large number of laboratories have investigated neurotransmitters, neuropeptides and hormonal systems as elements involved in food intake regulation in fish (Volkoff 2016, Delgado et al. 2017, Ronnestad et al. 2017) and mammals (Rui 2013, Rogers \& Brunstrom 2016, Heisler \& Lam 2017). We present a current picture of the functional crosstalk among neuroendocrine signals released from the brain and peripheral tissues in the context of homeostatic regulation of food intake (Fig. 4).

An exquisite balance of food ingestion and expenditure accomplishes energy homeostasis over long periods. Feeding exhibits a major homeostatic core sustained by a dual component, a short-term (meal to meal) regulation of food intake mediated by central and peripheral signals and a long-term feedback regulation (days to months) modulated by stores and food availability over prolonged time periods. Both mechanisms need to function in concert to integrate energy intake and expenditure to ensure the maintenance of energy balance (Havel 2001, van de Pol \&

ventral habenular nucleus; I, intermediate thalamic nucleus; IA, intercalated amygdalar nucleus; Int, internal capsule; LA, lateral amygdalar nucleus; LHA, lateral hypothalamus; ME, median eminence; MEA, medial amygdalar nucleus; mtt, mammillothalamic tract; NAPv, anterior periventricular nucleus; NAT, anterior tuberal nucleus; NC, cortical nucleus; NGa, anterior part of the nucleus glomerulosus; NGT, tertiary gustatory nucleus; NHd, dorsal habenular nucleus; NLOT, nucleus of the lateral olfactory tract, piramidal layer; NLTd, dorsal part of the lateral tuberal nucleus; NLTI, lateral part of the lateral tuberal nucleus; NLTm, medial part of the lateral tuberal nucleus; NLTV, ventral part of the lateral tuberal nucleus; NPC, central pretectal nucleus; NPGI, lateral preglomerular nucleus; NPGm, medial preglomerular nucleus; NPPv, posterior periventricular nucleus; NSC, suprachiasmatic nucleus; nst, nigrostriatal tract; opt, optic tract; OT, optic tectum; P, pituitary; PAA, piriform amygdalar area; $\mathrm{PC}$, paracommissural nucleus; PeF, perifornical area; PGZ, periventricular grey zone of the optic tectum; PIR, pyriform area; PM, magnocellular preoptic nucleus; PPA, pyriform amygdalar layer; PPd, dorsal periventricular pretectal nucleus; PR, perireunensis nucleus; PSm, magnocellular superficial pretectal nucleus; PSp, parvocellular superficial pretectal nucleus; PVH/PVN, paraventricular hypothalamic nucleus; PVi, periventricular hypothalamic nucleus intermediate part; $\mathrm{RCH}$, retrochiasmatic area; SBPV, subparaventricular zone; SI, substancia innominate; TLo, nucleus of the longitudinal torus; TPp, periventricular nucleus of the posterior tuberculum; TU, tuberal nucleus; V3, third ventricle; VAO, ventral accessory optic nucleus; Vc, central part of the ventral telencephalon; Vd, dorsal part of the ventral telencephalon; VI, lateral part of the ventral telencephalon; $\mathrm{VL}$, ventrolateral thalamic nucleus; VM, ventromedial nucleus of the thalamus; $\mathrm{VMH}$, ventromedial hypothalamic nucleus; Vs, supracommissural part of the ventral telencephalon; $\mathrm{V} v$, ventral part of the ventral telencephalon; $\mathrm{Xi}$, xiphoid thalamic nucleus; ZI, zona incerta. 


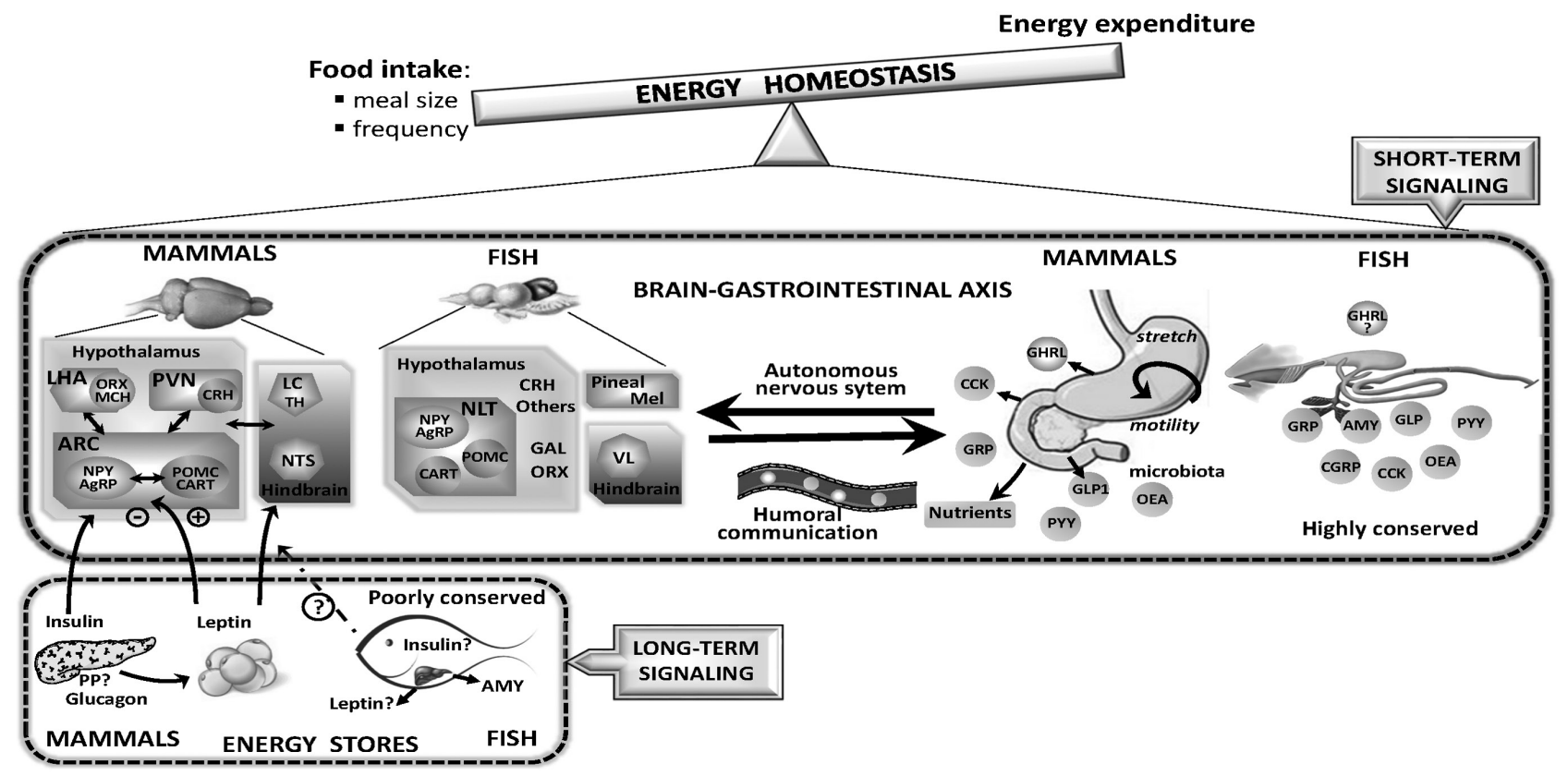

Figure 4

Schematic model summarizing the short- and long-term control of energy homeostasis integrating central and peripheral signals in mammals and fish. AgRP, agouti-related peptide; AMY, amylin; ARC, arcuate nucleus; CART, cocaine- and amphetamine-related transcript; CCK, cholecystokinin; CGRP, calcitonin gen-related peptide; CRH, corticotrophin-releasing hormone; GAL, galanin; GHRL, ghrelin; GLP1, glucagon-like peptide 1; GRP, gastric-related peptide; LC, locus coeruleus; LHA, lateral hypothalamic area; $\mathrm{MCH}$, melanocyte-concentrating hormone; Mel, melatonin; NPY, neuropeptide Y; NLT, nucleus lateral tuberal; NTS, nucleus of the tractus solitaries; OEA, oleoilethanolamide; ORX, orexin; PPY, pancreatic polypeptide; POMC, pro-opio melanocortin; PVN, paraventricular nuclei; TH, tyroxina hydroxilase; VL, vagal lobe.

Gorissen 2017). Overall, a plethora of hormonal, neural and metabolic inputs coordinated by the brain-gut axis controls alterations of energy intake and expenditure to meet a functional homeostasis.

In the short-term control, gastric satiation signals arise primarily from mechanical distention detected by mechanoreceptors that relay outputs via vagal and spinal sensory nerves to complex satiation circuits in the hypothalamus, which determines the ceasing of food intake (Cummings \& Overduin 2007). In fish lacking stomach, the intestinal bulb takes on this function. Intestinal satiation is mainly evoked by secretion of peptides from enteroendocrine cells in response to the presence of digestion products and metabolites, which can act as paracrine regulators and primary determinants of gut-brain satiety and as endocrine signals by direct actions on specific receptors located in hypothalamus and other brain areas (Heisler \& Lam 2017). A large number of endocrine signals highly conserved across the vertebrate lineage modulates food intake in this homeostatic shortterm circuit, and some of them are expressed in central locations, not only as part of this short-term homeostatic pathway but also as part of the hedonic pathway.
The long-term control of food intake in mammals is based on a negative feedback system involving communication of energy stores through adiposity signals to the brain. The main long-term adiposity hormones are insulin and leptin (Londraville et al. 2014, Deck et al. 2017, Hussain \& Khan 2017). Recently, this long-term modulation of satiety has been linked in mammals to the emerging role of gut microbiota in the stimulation of intestinal satiety pathways (Fetissov 2017), but this interesting subject has not been studied yet in fish.

\section{Short-term signalling from brain}

In mammals, the hypothalamic ARC neurons that coexpress NPY/AgRP and the neurotransmitter $\gamma$-aminobutyric acid (GABA) stimulate appetite, whereas neurons that coexpress CART/POMC decrease appetite (Waterson \& Horvath 2015). These neurons respond rapidly to peripheral signals of metabolic or endocrine nature such as leptin, insulin and ghrelin (GHRL), among others (Loh et al. 2015) and relay the signals to other brain areas to coordinate the overall balance between food intake and energy expenditure. 
NPY, one of the most highly conserved neuropeptides through vertebrate phylogeny (Blomqvist et al. 1992), is probably the most potent orexigenic signal in mammals (Mercer et al. 2011) and fish (López-Patiño et al. 1999, Matsuda et al. 2012). NPY is widely distributed in mammalian brain acting through Y1 receptor signalling pathway to stimulate feeding (Eva et al. 2006). In fish, neurons and nerve fibres containing NPY-like immunoreactivity are also widely detected in the brain (Cerdá-Reverter \& Larhammar 2000, Matsuda et al. 2012), and its orexigenic actions in many teleosts are mediated by Y1- and Y5-like receptors (de Pedro et al. 2000, Narnaware $\&$ Peter 2002). ARC NPY neurons are feeding centres interacting with a number of central appetite regulators of either orexigenic (CART, orexins, Kojima et al. 2009, Mercer et al. 2011, Volkoff 2016) or anorexigenic (melaninconcentrating hormone (MCH) Matsuda et al. 2009a) nature. These neurons integrate peripheral energy signals and hormones (GHRL, leptin and insulin) in mammals. In fact, NPY is a key mediator of orexigenic actions in both mammals and fish. NPY in mammals regulates energy utilization by enhancing storage in white adipose tissue, taking part of a hypothalamus-adipose tissue crosstalking (Zhang et al. 2014). Whether a similar feedback loop exists in fish remains elusive, but results from food deprivation studies do not support such a role (Jørgensen et al. 2016). Recent data suggest that NPY family and its receptors have various important functions beyond feeding regulation (Loh et al. 2015).

The melanocortin system, composed of peptides derived from POMC, their different receptor subtypes, endogenous antagonists (agouti signalling protein and AgRP) and accessory proteins emerged early in vertebrate evolution (Vastermark \& Schiöth 2011, Takahashi et al. 2016). This system is involved in the central regulation of feeding in fish (Cerdá-Reverter et al. 2011, Cal et al. 2017). In mammals, the $\alpha$-melanocyte-stimulating hormone ( $\alpha$ $\mathrm{MSH}$, product of POMC) is an anorexigenic peptide that activates MC4R resulting in food intake inhibition (Loh et al. 2015), while the antagonism of this receptor by AgRP exerts orexigenic actions (Rui 2013, Sohn 2015, Takeuchi 2016). Studies in cyprinids and salmonids (Kojima et al. 2010, Zhang et al. 2012, Dalmolin et al. 2015, Guillot et al. 2016) suggest that AgRP would counteract the basal inhibition of feeding induced by the melanocortin system (Kojima et al. 2010, Zhang et al. 2012, Dalmolin et al. 2015, Guillot et al. 2016).

Orexins are brain peptides that regulate food intake, among other physiological functions (Sakurai 2006). The well-conserved sequences of orexins and their receptors

๑) 2018 Society for Endocrinology Published by Bioscientifica Ltd. Printed in Great Britain from fish to mammals (Wong et al. 2011), together with its broad distribution in brain areas related to food intake control (Volkoff et al. 1999, Pitts \& Volkoff 2017) support a high functional conservation of these peptides. Orexins show orexigenic actions early in vertebrate phylogeny. In fish, most functional studies were carried out in cyprinids, where stimulation of feeding behaviour (and interactions with other feeding regulators, as NPY and GHRL, Miura et al. 2007) is a general rule. However, this is not the case in other fish orders, such as perciforms, where orexins are involved in locomotor activity not feeding (Volkoff 2016).

Many other brain neuropeptides regulate food intake in vertebrates, but their role is unclear in some cases. CART shows anorexigenic actions in mammals (Kuhar et al. 2002, Hunter et al. 2004), whereas in fish, the anorectic effect is species specific possibly due to the existence of several gene isoforms (Volkoff 2016, Ronnestad et al. 2017). The hypothalamic MCH exerts orexigenic actions in mammals mediated by $\alpha-\mathrm{MSH}$ and orexin (Tritos \& Maratos-Flier 1999, Nahon 2006), whereas in fish, its effect is dependent on the species assessed (Volkoff 2016) and seems to be affected by body colour for background adaptation (Matsuda et al. 2009b). Galanin is a shortterm orexigenic peptide in mammals (Lang et al. 2015) expressed in brain and gut. In fish, central administration of galanin (de Pedro et al. 1995a,b, Guijarro et al. 1999), periprandrial changes of brain transcript and its induction by short-term fasting (Volkoff \& Peter 2001, Mensah et al. 2010) support an orexigenic role, at least in cyprinids. Finally, some members of the family of biologically active RFamide peptides (Chartrel et al. 2006), present in all vertebrate phyla with a fully conserved biological active C-terminal domain, seem to be involved in the central control of food intake in fish (Liu et al. 2009) and mammals (Chartrel et al. 2011).

\section{Sort-term signalling from GIT}

Enteroendocrine cells represent the largest endocrine tissue in the organism and secrete a wide range of peptides affecting redundantly a variety of processes regulating food intake. By using mechanosensing and chemosensing mechanisms, gastrointestinal (GI) hormones are primary determinants of satiety and limit the size of individual meals to maintain an efficient digestion and absorption (Steenseles \& Depoortere 2018). As a rule, they act as shortterm signals by influencing GIT motility and secretions, and by transmitting information locally in a paracrine fashion, and at central feeding centres via direct vagal 
afferent projections or through bloodstream (Cummings \& Overduin 2007). In mammals, at least 12 subtypes of enteroendocrine cells secrete more than 20 different peptides (Rehfeld 2004). Thus, GHRL, gastrin-releasing peptide (GRP), cholecystokinin (CCK), glucagon-like peptide 1 (GLP-1), pancreatic polypeptide (PP), peptide tyrosine tyrosine (PYY) and oxyntomodulin, among others, have been implicated in appetite regulation (Cummings \& Overduin 2007, Sam et al. 2012). However, their roles were assessed partially in a limited number of fish species (Nelson \& Sheridan 2006, Volkoff 2016).

Mostly secreted from the stomach, GHRL is the most potent peripherally produced peptide exerting a stimulatory effect on food intake in mammals. Feeding and nutritional status are the main factors regulating ghrelinergic system in mammals (Müller et al. 2015) and in some teleosts (Blanco et al. 2016). The orexigenic action of GHRL is observed in some fish species (Riley et al. 2005, Unniappan \& Peter 2005, Matsuda et al. 2006, Tinoco et al. 2014a, Velasco et al. 2016a), but not always in others (Jönsson 2013), and the recent identification of divergent GHRL receptors in teleosts (Tine et al. 2016) might underpin such variability. The orexigenic effects of GHRL are mainly mediated by the activation of glutamatergic afferents onto ARC NPY/AgRP neurons in rodents (Loh et al. 2015, Sohn 2015, Heisler \& Lam 2017). In fish, not only orexigenic signals (NPY and orexin, Miura et al. 2006, 2007), but also anorexigenic central (corticotrophin-releasing factor, CRF, Jönsson et al. 2010) and enteric (CCK, PYY and GLP-1, Blanco et al. 2017) signals are implicated.

As indicated earlier, gastric satiation signals arise primarily from mechanical distention, but the presence of food-derived chemicals in the luminal gut is also a potent satiation signal. Fat and small peptides from digestion induce the release of CCK (Moran \& Kinzig 2004), a peptide also produced in mammalian hypothalamus during feeding (Beinfeld 1983). Both central and enteric CCK reduce meal size by activation of central (CCK2R) and gut (CCK1R) receptor subtypes in mammals (Schneeman 2004). In fish, the well-conserved isoform CCK-8 reduces food intake (Himick \& Peter 1994) and CCK mRNA levels increase postprandially (Peyon et al. 1999, Ji et al. 2015). Part of the anorexigenic effect of CCK may result from the inhibition of gastric emptying in mammals (Cummings \& Overduin 2007) and fish (Tinoco et al. 2015), but additional mechanisms are involved. For example, a synergistic interaction with long-term adiposity signals (leptin or insulin) might occur in mammals (Morton et al. 2006) and fish (Volkoff et al. 2003).
Proglucagon-derived peptides (glucagon, glicentin, oxyntomodulin and GLP) produced by enteroendocrine cells act as satiety factors in mammals through a network of central and peripheral targets (Sandoval \& D'Alessio 2015), but scarce information exists regarding this role in fish. Possible modulatory roles among enteric peptides have recently been suggested in fish, e.g. GHRL interacts with some of these proglucagon-derived peptides (Blanco et al. 2017), in support of the actions of these peptides on the regulation of energy homeostasis (Mommsen \& Moon 1989, Mojsov 2000, Polakof et al. 2011a).

Finally, some GI fatty acid ethanolamines, structural analogues of the endocannabinoids, as oleoylethanolamide (OEA) induces satiety in mammals (Fu et al. 2003) and goldfish (Tinoco et al. 2014b), where it is involved in the regulation of liver lipid and glucose metabolism (GómezBoronat et al. 2016). In the rat, OEA modulates feeding by prolonging the time interval between meals rather than meal size (Gaetani et al. 2003).

\section{Long-term signalling}

The pathways described earlier relaying short-term neuroendocrine signals from the gut to the brain interact with long-term signals that modulate the sensitivity of vagal and hindbrain responses to GIT satiation signalling (Cummings \& Overduin 2007). The long-term signals in mammals are primarily humoral, adiposity hormones acting in the brain to regulate short-term food intake and, at the end, achieve long-term energy balance (Yamada et al. 2006). Then, the link between adiposity and food intake in mammals hinges on a negative feedback system using adiposity signals to communicate fat stores to the brain (Fig. 4).

In mammals, adipose tissue is the main long-term energy store, and a variety of hormones are produced in the adipocytes, such as leptin (Morris \& Rui 2009), which is considered as a lipostat or circulating indicator of nutritional status. Leptin is the key long-term satiety signal in mammals, but it can also be considered as an allostatic hormone relating energy status to adaptive responses of multiple physiological systems in vertebrates, including fish (Copeland et al. 2011, Friedman 2014). Leptin in mammals provides information on total energy stored, reduces food intake by inhibiting orexigenic NPY/AgRP and stimulating anorexigenic POMC/CART neurons in ARC and by stimulation of energy expenditure (Morrison 2005, Ahima 2006). Therefore, leptin in mammals restores energy balance under energy surplus conditions (Schneeberger et al. 2014, Hussain \& Khan 2017). 
However, published data in fish do not support such lipostatic role of leptin, whose origin is not the adipose tissue but the liver. Leptin levels rise postprandially and reduce food intake in some teleosts (de Pedro et al. 2006, Tinoco et al. 2012, Won et al. 2012). However, diverse and inconsistent responses to fasting/adiposity are reported (Jørgensen et al. 2016, Volkoff 2016, Delgado et al. 2017), and no changes in adiposity were observed in leptin receptor-deficient zebrafish (Michel et al. 2016). Although tertiary structure of leptin is well preserved, the poor primary sequence conservation between mammalian and fish leptins (Gorissen et al. 2009), and the multiple leptin paralogues demonstrated in teleosts may underly such a variety of different functional properties. Nevertheless, a broader physiological role for leptin beyond nutritional status signalling is currently accepted in fish (van de Pol et al. 2017). An interplay between leptin and insulin is described in mammals (Deck 2017, Hussain \& Khan 2017), where this peptide meets the criteria to be an adiposity signal, conveying fat store information to the brain, with anabolic functions at the periphery and catabolic effects in the hypothalamus (Havel 2001). The anorexigenic action of insulin and its mechanism of action are clear in mammals, whereas in fish, differences occur between species (Delgado et al. 2017, van de Pol et al. 2017).

\section{Hedonic regulation}

Both homeostatic and hedonic/motivational neurocircuits are triggered during feeding but activation level may shift depending on the type of food and/or the physiological state of the animal (Rossi \& Stuber 2017). Overlapping of these neuronal pathways provides an anatomical basis to the food preference/indifference according to the energy status (Castro et al. 2015, Rossi \& Stuber 2017). Projections from LH to VTA and subsequent innervation to subpallial areas constitute a part of the key neuronal circuitry regulating reward processes in vertebrates. Therefore, NAc and ventral pallidum are recipient hotspots with special roles in mediating the hedonic impact 'liking' and motivational incentive salience 'wanting' of food rewards. The interactions of these subpallial structures with $\mathrm{LH}$ permit regulatory hunger/satiety modulation of food motivation and reward (Nogueiras et al. 2012, Castro et al. 2015, Tyree \& de Lecea 2017).

The mesolimbic dopamine system has long been involved as a key player of goal-directed behaviour including feeding (Palmiter 2007) and the importance of the $\mathrm{SNc} / \mathrm{VTA}$ projections to subpallial areas (NAc, CPu and dorsal striatum) has been underlined in mammals (Hnasko et al. 2006, Rossi \& Stuber 2017). The involvement of dopamine in food reward relates to incentive motivation of feeding ('wanting') since mice unable to produce dopamine die by starvation (Zhou \& Palmiter 1995). Some other hormonal systems encoding body energy status like leptin, insulin, GHRL and glucocorticoids are also able to modulate dopaminergic mesolimbic pathways in a clear example of homeostatic and hedonic/motivational pathway overlapping (Palmiter 2007, Volkow et al. 2011, Rossi \& Stuber 2017). These results sharply differ from those reporting an inhibitory effect on feeding levels when dopamine is administrated in the perifornical hypothalamic area (Leibowitz \& Rossakis 1979). Therefore, dopamine signalling in the hypothalamus exhibits inhibitory effects but, in contrast, mesostriatal dopamine is essential for feeding in mammals (Palmiter 2007). Studies focusing on hedonic regulation of feeding behaviour and particularly dopamine effects on food reward circuitry in fish are very limited. Thus, in sea bass, oral administration of L-DOPA severely inhibits food intake (Leal et al. 2013), whereas in goldfish, i.c.v. administration of dopamine receptor agonists inhibit food intake (de Pedro et al. 1998). These effects are consistent with the hypothalamic effects of dopaminergic signalling which together with the resemblances between dopaminergic ascending pathways in the mammalian and teleost brain (Yamamoto et al. 2011) suggests the involvement of dopaminergic system in the motivational regulation of feeding in fish. Results from self-feeding experiments carried out in fish can be used to provide information regarding this issue (Geurden et al. 2007, Rubio et al. 2008, Leal et al. 2009, 2011, 2013, Attia et al. 2012, Klaren et al. 2013). A recent study (Soares et al. 2017) reported that dopamine disruption contributes to shift the attribution of motivational incentive from the predictive cue towards the actual experimental reward, the food. This result supports the dopaminergic role in the motivational aspects of food intake in fish but more research is required to support such a hypothesis.

The opioid system plays an important role in neural reward processes as the opioid receptor antagonists attenuate appetite for palatable food (Nogueiras et al. 2012). Unfortunately, the effect of opioids on feeding behaviour in fish has been scarcely asssessed. Thus, central administration of $\beta$-endorphin stimulates food intake in goldfish, whereas naloxone prevents opioid effect on feeding (de Pedro et al. 1995a,b). Similarly, endocannabinoids such as 2-arachidonoylglycerol and anandamide (AEA) are able to modulate not only homeostatic hypothalamic systems but also the dopaminergic mesolimbic circuitry thus affecting reward 
systems (Lau et al. 2017). Available studies showed that AEA regulates feeding levels (Valenti et al. 2005, Piccinetti et al. 2010) but again there are no studies on reward systems.

\section{Nutrient signalling}

The detection of changes in nutrient levels in vertebrate brain is an essential process involved in the regulation of food intake and energy expenditure (Berthoud \& Morrison 2008, Blouet \& Schwartz 2010, Morton et al. 2014). Accordingly, several mechanisms are present in brain areas, especially hypothalamus to detect changes in the levels of glucose, fatty acids and amino acids, as partially demonstrated in mammals (Efeyan et al. 2015) and to a lesser extent in fish (Soengas 2014, Conde-Sieira \& Soengas 2017).

\section{Glucose}

In mammals, the detection of changes in glucose levels by glucosensing mechanisms results in regulatory responses including food intake (Marty et al. 2007, Steinbusch et al. 2015). Accordingly, reduced glycaemia increases food intake, whereas enhanced glycaemia decreases food intake (Morton et al. 2014, Ogunnowo-Bada et al. 2014, Rogers et al. 2016). Despite fish being considered glucoseintolerant species (Polakof et al. 2011b, 2012), a control of glucose levels exists in tissues relying on glucose such as the brain (Soengas \& Aldegunde 2002). Accordingly, decreased food intake occurred in fish fed with a carbohydrateenriched diet (Narnaware \& Peter 2002, Polakof et al. 2008b,c, Saravanan et al. 2012, Figueiredo-Silva et al. 2013, Castro et al. 2015, Xu et al. 2018) or after hyperglycaemic treatments (Ruibal et al. 2002, Polakof et al. 2007, 2008a, Conde-Sieira et al. 2010a,b, 2012). Furthermore, increased food intake occurred in fish-fed diets with reduced levels of carbohydrates (Sánchez-Muros et al. 1998, Capilla et al. 2003, Polakof et al. 2008b,c) or after hypoglycaemic treatments (Polakof et al. 2007, 2008a, Conde-Sieira et al. $2010 a, b)$.

Several glucosensing mechanisms have been suggested in mammals (Fig. 5). The best known is that mediated by glucokinase (GK) (Marty et al. 2007, Polakof et al. 2011b, Efeyan et al. 2015, Steinbusch et al. 2015). Glucose taken up by glucose facilitative carrier type 2
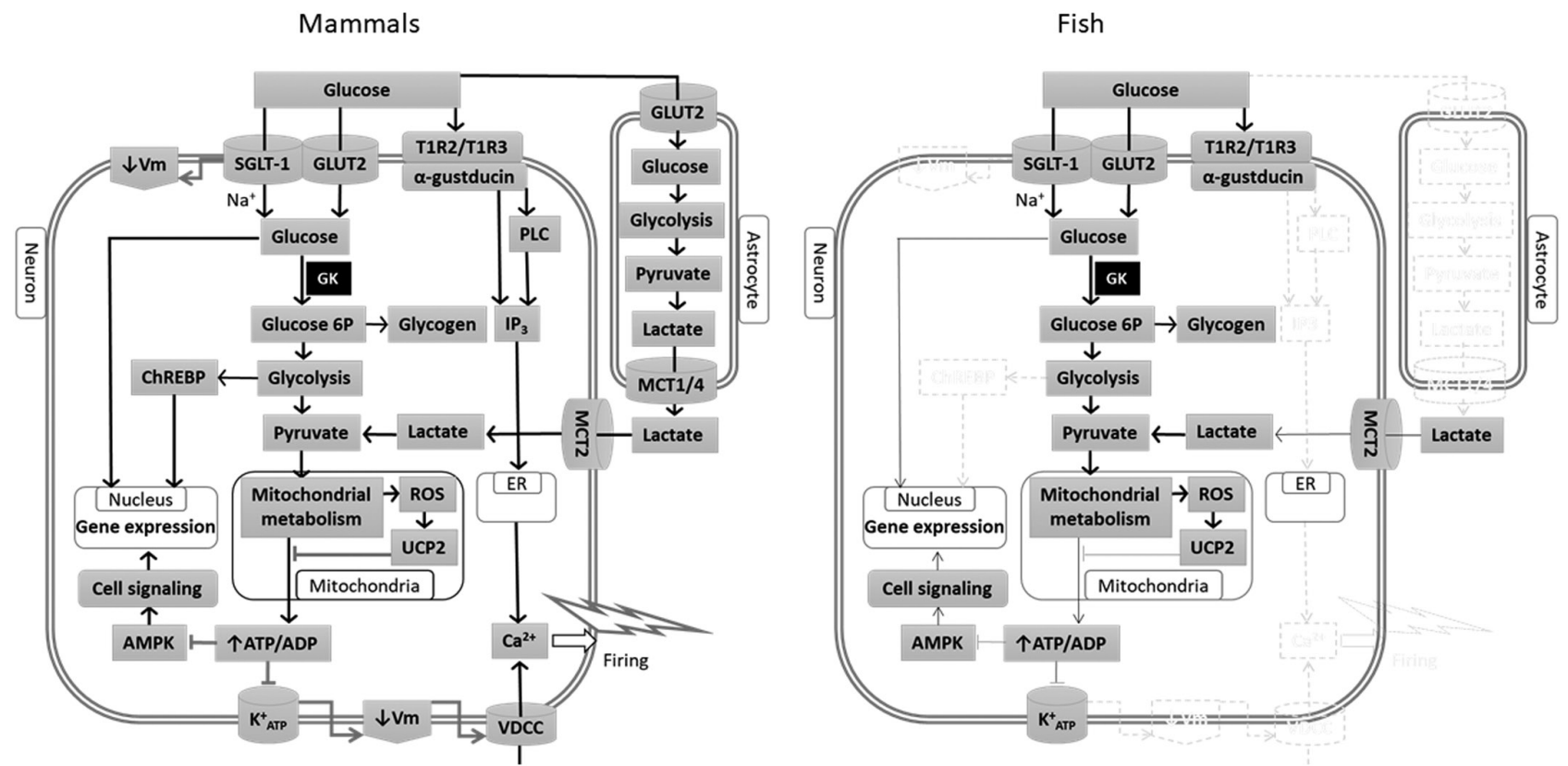

Figure 5

Schematic drawing with a model of processes involved in glucose sensing in hypothalamus of mammals and fish. Dotted symbols, unknown in fish; black thick line, demonstrated activation; black thin line, partially demonstrated activation; grey thick line, demonstrated inhibition; grey thin line, partially demonstrated inhibition; AMPK, AMP-activated protein kinase; ChREBP, carbohydrate-responsive element-binding protein; ER, endoplasmic reticulum; $\mathrm{K}^{+}{ }_{\text {ATP }}$ inward rectifier ATP-dependent $\mathrm{K}^{+}$channel; GK, glucokinase (hexokinase IV); GLUT2, facilitative glucose carrier type 2; IP ${ }_{3}$, inositol 1,4,5-triphosphate; PLC, phospholipase C; MCT, monocarboxylate carrier; SGLT-1, sodium/glucose co-transporter 1; ROS, reactive oxygen species; T1R2, type 1 taste receptor subunit 2; T1R3, type 1 taste receptor subunit 3; UCP2, uncoupling protein 2; VDCC, L-type voltage-dependent calcium channel; Vm, membrane potential. 
(GLUT2) is phosphorylated to glucose 6-phosphate by $\mathrm{GK}$, and then metabolized through glycolysis to increase intracellular ATP/ADP ratio. This induces closure of ATPdependent inward rectified potassium channel $\left(\mathrm{K}^{+}{ }_{\text {ATP }}\right)$ resulting in membrane depolarization and subsequent entry of calcium into the cell. There is also evidence in mammals for GK-independent glucosensing mechanisms. These include (1) enhanced expression of liver $\mathrm{X}$ receptor (LXR) (Mitro et al. 2007, Kruse et al. 2017), (2) activation of intracellular signalling cascade by sweet taste receptors (Herrera Moro Chao et al. 2016, Kohno 2017), (3) enhanced expression of sodium/glucose co-transporter 1 (SGLT-1) (González et al. 2009, Thorens 2012) and (4) increased expression of uncoupling protein 2 (UCP2) in response to mitochondrial production of reactive oxygen species (ROS) (Beall et al. 2010, Diano \& Horvath 2012). Evidence obtained in recent years also supported the presence in fish hypothalamus of comparable glucosensing mechanisms (Fig. 5) based on GK (Conde-Sieira \& Soengas 2017), LXR and sweet taste receptor (Otero-Rodiño et al. 2015a, 2016, Balasubramanian et al. 2016). Despite the reduced importance of glucose metabolism in fish (Polakof et al. 2012), the presence and functioning of central glucosensing mechanisms is comparable to that described in mammals. However, important topics, such as the electrophysiological response of hypothalamic neurons to glucose, the role of carbohydrate-responsive element-binding protein (ChREBP) or the signalling pathway of sweet taste receptors are still unknown in fish. Furthermore, the functioning of glucosensing neurons relates in mammals to the presence of an astrocyte-neuron lactate shuttle (Pellerin \& Magistretti 2012) for which no clear evidence is available in fish (Polakof \& Soengas 2008, Otero-Rodiño et al. 2015b).

\section{Fatty acids}

Lipids are major nutrients in fish supporting many different processes (Sheridan 1994, Tocher 2003, Polakof et al. 2010). In a way comparable to mammals (Morton et al. 2014), a decrease in food intake usually occurred in fish fed a lipid-enriched diet (Silverstein et al. 1999, Williams et al. 2006, Figueiredo-Silva et al. 2012b, Saravanan et al. 2013, Bonacic et al. 2016, Li et al. 2016), with high levels of fatty acid in plasma (Luo et al. 2014) or with large lipid stores (Shearer et al. 1997, Silverstein et al. 1999, Johansen et al. 2002, 2003). Recent studies in rainbow trout showed a decrease in food intake after administration of oleate or octanoate (Librán-Pérez et al. 2012, 2014, Velasco et al. 2016a,b). The effect of oleate but
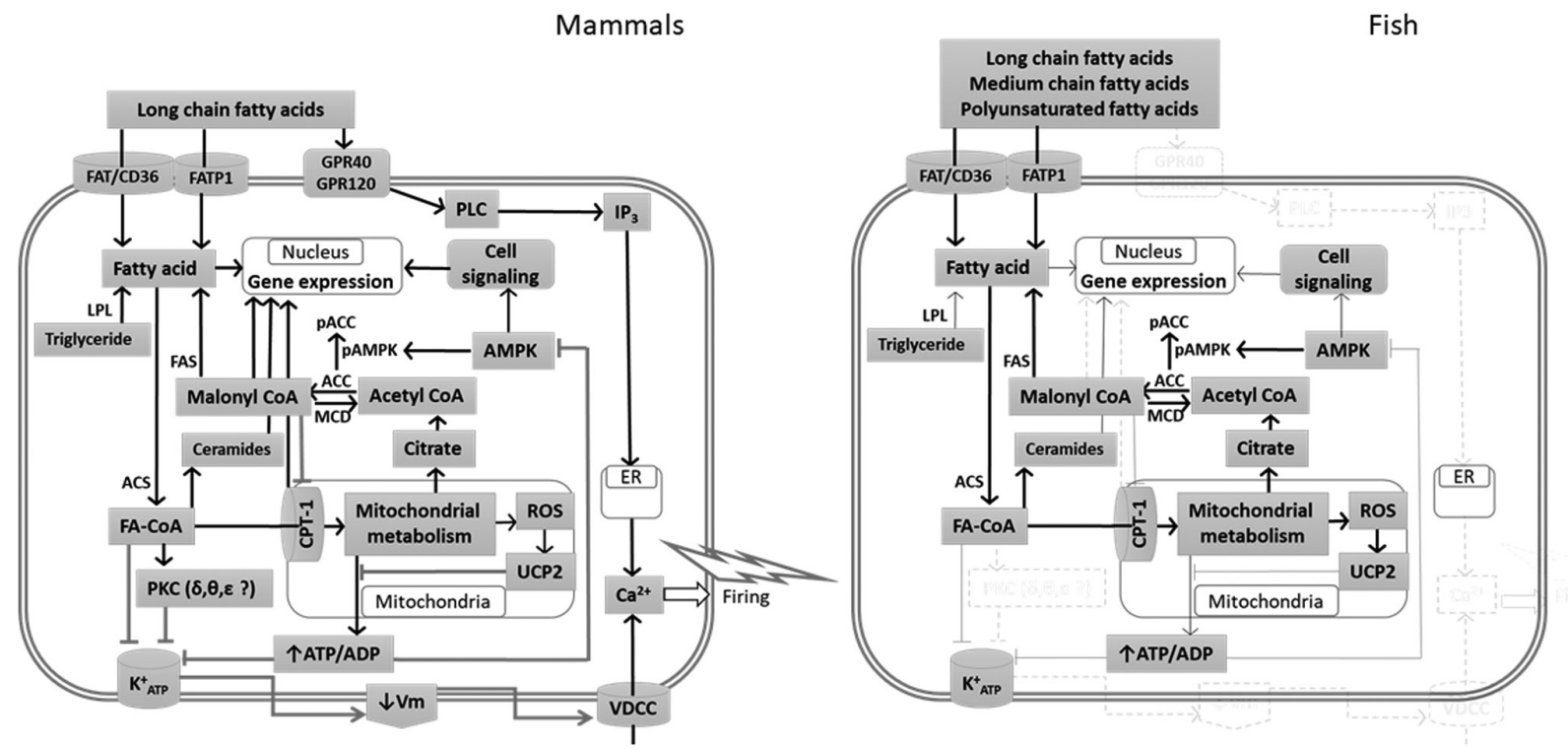

Figure 6

Schematic drawing with a model of processes involved in fatty acid sensing in hypothalamus of mammals and fish. Dotted symbols, unknown in fish; black thick line, demonstrated activation; black thin line, partially demonstrated activation; grey thick line, demonstrated inhibition; grey thin line, partially demonstrated inhibition; ACC, acetyl-CoA carboxylase; ACS, acetyl-CoA synthetase; AMPK, AMP-activated protein kinase; CPT-1, carnitine palmitoyl transferase type 1; ER, endoplasmic reticulum; FAS, fatty acid synthase; FAT/CD36, fatty acid translocase; FATP1, fatty acid transporter protein type 1; $\mathrm{K}^{+}{ }_{\mathrm{ATP}}$ inward rectifier ATP-dependent $\mathrm{K}^{+}$channel; $\mathrm{IP}_{3}$, inositol 1,4,5-triphosphate; GPR40, G-protein-coupled receptor 40; GPR120, G-proteincoupled receptor 120; LPL, lipoprotein lipase; MCD, malonyl-CoA decarboxylase; PLC, phospholipase C; PKC, protein kinase C; ROS, reactive oxygen species; UCP2, uncoupling protein 2; VDCC, L-type voltage-dependent calcium channel; Vm, membrane potential. 
not octanoate is comparable to that reported in mammals (López et al. 2007, Hu et al. 2011).

Mammalian hypothalamus detects changes in the levels of specific long-chain fatty acids (LCFA) through fatty acid-sensing mechanisms (López et al. 2007, Magnan et al. 2015) (Fig. 6). The detection of raised LCFA levels occurs through (1) increased levels of malonyl-CoA inhibiting carnitine palmitoyl transferase-1 (CPT-1) then avoiding mitochondria to import fatty acid-CoA for oxidation, (2) increased capacity of fatty acid translocase (FAT/CD36), (3) activation of specific isoforms of protein kinase $\mathrm{C}$ resulting in the inhibition of $\mathrm{K}^{+}{ }_{\mathrm{ATP}}$, (4) increased capacity of mitochondria to produce ROS inhibiting $\mathrm{K}^{+}{ }_{\text {ATP }}$, (5) enhanced lipoprotein lipase (LPL) activity and (6) enhanced activity of G-protein-coupled receptors 40 (GPR40) and 120 (GPR120). Available studies in fish (Fig. 6) support the presence of comparable fatty acidsensing mechanisms in hypothalamus of rainbow trout (Librán-Pérez et al. 2012, 2013, 2014, 2015, Velasco et al. 2016a), Senegalese sole (Conde-Sieira et al. 2015), and grass carp (Li et al. 2016, Gong et al. 2017). However, there are two clear differences when comparing fish and mammals. The first is the ability of fish to detect changes in the levels of medium-chain fatty acid (MCFA) like octanoate. This ability might relate to the relative high abundance of MCFA in body lipids (Davis et al. 1999, Trushenski 2009) and/or the high capacity for MCFA oxidation (FigueiredoSilva et al. 2012a), in contrast to mammals (Ooyama et al. 2009). The second difference is fish capacity to respond to changes in the levels of specific polyunsaturated fatty acid (PUFA) of the $n-6$ and particularly n- 3 series as demonstrated in Senegalese sole (Conde-Sieira et al. 2015) in contrast with the lack of response in mammals (Schwinkendorf et al. 2011, Greco et al. 2014). This difference might relate to the importance of n-3 PUFA in fish diets (Sargent et al. 2002) and tissues (Mourente $\&$ Tocher 1992, Tocher 2003). Despite achievements of recent years in fish, additional research is necessary to assess among others the putative role of PKC, GPR40 and GPR120, as well as the electrophysiological response of neurons to the presence of fatty acids.

\section{Amino acids}

The metabolic regulation of food intake induced by changes in levels of amino acids is largely unknown in mammals (Laeger et al. 2014). Only essential amino acids are involved in food intake regulation, specifically through sensing of specific branched-chain amino acids (BCAA) such as leucine (Duan et al. 2016, Heeley \& Blouet

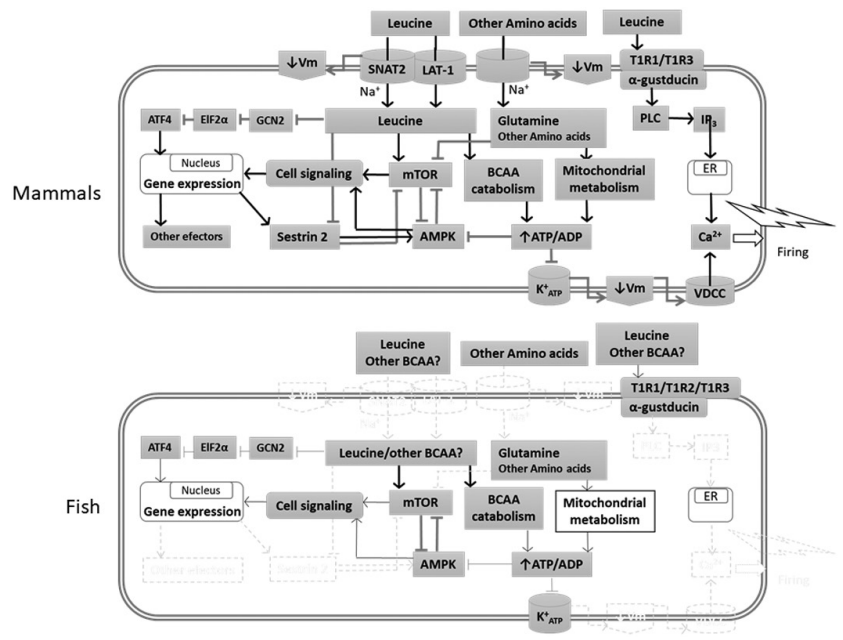

Figure 7

Schematic drawing with a model of processes involved in amino acid sensing in hypothalamus of mammals and fish. Dotted symbols, unknown in fish; black thick line, demonstrated activation; black thin line, partially demonstrated activation; grey thick line, demonstrated inhibition; grey thin line, partially demonstrated inhibition; AMPK, AMP-activated protein kinase; ATF4, activatory transcription factor 4; BCAA, branchedchain amino acid; eIF $2 \alpha$, eukaryotic initiation factor $2 \alpha$; ER, endoplasmic reticulum; GCN2, general control non-derepressible 2 kinase; $\mathrm{K}^{+}{ }_{\mathrm{ATP}}$ inward rectifier ATP-dependent $\mathrm{K}^{+}$channel; $\mathrm{IP}_{3}$, inositol

1,4,5-triphosphate; LAT-1, L-amino acid transporter 1; mTOR, mechanistic target of rapamycin; PLC, phospholipase C; SNAT2, system A amino acid transporter 2; T1R1, type 1 taste receptor subunit $1 ; \mathrm{T} 1 \mathrm{R} 2$, type 1 taste receptor subunit 2; T1R3, type 1 taste receptor subunit 3; VDCC, L-type voltage-dependent calcium channel; $\mathrm{Vm}$, membrane potential.

2016) whose increased levels inhibit food intake (Blouet \& Schwartz 2012, Morrison et al. 2016). This process occurs through not completely understood mechanisms (Fig. 7), based on (1) activation of BCAA metabolism (Morrison \& Laeger 2015), (2) activation of glutamine metabolism (Jewell \& Guan 2013), (3) activation of mechanistic target of rapamycin (mTOR) (Cavanaugh et al. 2015, Hu et al. 2016) and/or inhibition of AMP-activated protein kinase (AMPK) signalling (Fromentin et al. 2012), (4) umami taste receptor signalling (Wauson et al. 2012) and (5) sestrin 2 activation (Wolfson \& Sabatini 2017). The response is specific since another BCAA such as valine does not elicit activation of these systems or changes in food intake (Fromentin et al. 2012). Furthermore, the deficiency in essential amino acids (including BCAA) enhanced food intake through an amino acid-sensing system mediated by general control non-derepressible 2 (GCN2) kinase (Maurin et al. 2014, Morrison \& Laeger 2015).

Having high dietary protein requirements, teleost fish are strongly dependent on dietary protein/amino acid levels (Wilson 1986). For instance, amino acids are the preferred carbon source for lipogenesis instead of glucose (Dai et al. 2016) in contrast to mammals (Blouet et al. 
2006). Accordingly, diets high in amino acids/protein inhibit food intake, whereas poor diets stimulate food intake (Suárez et al. 2002, Skiba-Cassy et al. 2013). A recent study (Comesaña et al. 2018) demonstrated decreased food intake in fish i.c.v. treated with leucine, which can be associated with the presence of putative amino acidsensing systems in hypothalamus, dependent on BCAA metabolism, glutamine metabolism, mTOR, umami taste receptors and GCN2 signalling (Fig. 7). These responses are comparable to those characterized in mammals $\mathrm{Hu}$ et al. 2016, Heeley \& Blouet 2016) with the exception of the type of subunits involved in umami taste signalling. Nevertheless, contrary to mammals, valine had a clear orexigenic effect in parallel with changes in amino acid sensing in telencephalon but not in hypothalamus (Comesaña et al. 2018). Compared with the other nutrients, the research on amino acid sensing is rather preliminary in fish, and important topics are unknown such as the role of sestrin 2, the signalling pathway of umami taste receptors, the carriers involved in amino acids uptake or the electrophysiological responses to the presence of amino acids. Considering the high importance of amino acids for fish metabolism, the existence of fish-specific unknown features of amino acid sensing compared with mammals is a reasonable hypothesis.

\section{Other signalling}

\section{Rhythms}

The cyclic changes of food resources provided a selective pressure for the emergence of food intake daily rhythms and seasonal feeding/fasting cycles in most vertebrates. Whether feeding circadian rhythms are endogenously regulated or just passive responses to the food availability is still under discussion, but many studies demonstrate that feeding cycles are entrained endogenously to anticipate and respond to predictable changes of food availability (López-Olmeda \& Sánchez-Vázquez 2010). Underlying rhythms in food intake, there is a timekeeping system that includes molecular clocks located in both brain and peripheral organs synchronized by cyclic environmental changes. Early studies demonstrate in rodents that the lightentrainable master clock within the circadian timekeeping system in mammals, the hypothalamic suprachiasmatic nucleus (SCN), is a functional clock necessary for the circadian expression of feeding behaviour (Nagai et al. 1978, Turek et al. 2005), and interactions between food anticipation and this master clock have been described (Blum et al. 2012). However, other clocks located in brain and peripheral organs, and not the SCN, appear to be the site of entrainment for food-derived cues (Feillet et al. 2006). In fact, feeding time produces phase-shifts of circadian clocks located not only in the liver and other peripheral organs (Stokkan et al. 2001, Mendoza \& Challet 2009, Bae \& Androulakis 2017), but also in mammalian brain regions involved in energy homeostasis, such as the hypothalamic PVN and ARC nuclei (de Araujo et al. 2016). In fish, where the circadian system is organized as multiple federated oscillators widely distributed through the organism (Moore \& Whitmore 2014, Isorna et al. 2017), mealtime resets the circadian expression of clock genes rhythms in some peripheral organs such as liver, gut and interrenal tissue (Feliciano et al. 2011, Nisembaum et al. 2012, Sánchez-Bretaño et al. 2015).

The food anticipation is manifested by food anticipatory activity, i.e. the increase in food-seeking activity in anticipation of mealtime when food access is restricted to a daily schedule (Stephan 2002). This food anticipatory activity, observed in mammals (Mistlberger 2011) and fish (Aranda et al. 2001, Vera et al. 2007) is independent of SCN and provides evidence of the key role played by mealtime in the synchronization of circadian system (Stephan 2002). A food-entrainable oscillator (FEO) is required to drive the entrainment of physiological and behavioural rhythms in response to food intake schedule, but remains unidentified (Blum et al. 2012, Carneiro \& Araujo 2012). Some studies suggest that such FEO may reside in a network of pacemakers, and neural and endocrine factors would participate in conveying peripheral metabolic information to the brain for the generation of food entrainment (Mendoza et al. 2010, Acosta-Galvan et al. 2011). Recent studies (Delezie et al. 2016) show that Rev-Erb $\alpha$, a nuclear receptor expressed rhythmically in the SCN and peripheral clocks, involved in the regulation of glucose and lipid metabolism (Everett \& Lazar 2014), is required for neural network-based prediction of food availability. Moreover, Rev-Erba seems to modulate hypothalamic orexinergic system to influence food reward behaviour in mice (Feillet et al. 2017), highlighting the molecular link among circadian rhythms, metabolism and feeding behaviour. Some hormones that participate as internal synchronizers may also provide signals to inform central oscillators about the timing of food intake. In this sense, orexigenic afferent pathways of the FEO have been considered to promote food anticipatory activity (Feillet et al. 2006) and orexigenic neurons are controlled by the circadian system (Blasiak et al. 2017). In fish, orexins play a role in the crosstalking between orexigenic peptides, 
as GHRL and NPY, and act as an input to the circadian system, synchronizing locomotor activity rhythms in the absence of external zeitgebers (Nisembaum et al. 2014). GHRL in both mammals and fish is a promoting factor in the generation of the food anticipatory activity and regulates clock genes expression at peripheral organs then considered as an input of the circadian system (LeSauter et al. 2009, Sánchez-Bretaño et al. 2015, 2017). Finally, the daily release of glucocorticoids is one of the most robust endocrine outputs of the circadian system anticipating feeding in both diurnal and nocturnal animals (Spiga et al. 2014). Thus, glucocorticoids are good candidates to communicate metabolic information from the periphery into the brain, and this is a conserved role in the functional organization of the peripheral circadian system in vertebrates (Sánchez-Bretaño et al. 2016, Isorna et al. 2017). The presence in mammals of glucocorticoid response elements in the promoters of the core clock genes supports the entrainment of peripheral clocks by these hormones (Yamamoto et al. 2005, Reddy et al. 2007, Schibler et al. 2015). In fish, such responsive elements remain unexplored, but certain clock genes are targets for glucocorticoids in the regulation of a peripheral oscillator highly sensitive to feeding entrainment, as the liver (Sánchez-Bretaño et al. 2015, 2016). These clocks located in metabolic organs, such as the liver, and reset by feeding cues, play a key role for the integration of systemic and nutritional signals provided by the feeding/ fasting cycle.

\section{Stress}

The hypothalamic-sympathetic chromaffin cells (HSC) and the hypothalamic-pituitary-interrenal (HPI, the equivalent of the hypothalamic-pituitary-adrenal axis or HPA) axes mediate the stress response in fish. Similar to the HPA, HPI begins with the synthesis of CRF in the POA or PVN and culminates with the production of cortisol, the main fish glucocorticoid. Preoptic CRF neurons modulate corticotropic cell activity in the pituitary to stimulate POMC production that is next processed to adrenocorticotropic hormone (ACTH). Subsequently, ACTH reaches interrenal tissue where it binds to melanocortin 2 receptor (MC2R), in the presence of melanocortin receptor accessory protein 1 (MRAP1), to promote cortisol synthesis and release (Cerdá-Reverter et al. 2011, 2013). An increase in glucocorticoid levels in plasma is one of the most evolutionary conserved stress responses in vertebrates and mediates many effects of stress including food intake (Wenderlar Bonga 1997).
A common response in fish to acute stress is the immediate reduction of food intake levels, which recovers after stressful conditions cease (Leal et al. 2011, Guillot et al. 2016). A similar response induced by stress and/or exogenous glucocorticoids can be observed in rodents but not in humans (Hewagalamulage et al. 2016). In fish, the stress-induced feeding response can be replicated by sustained administration of cortisol (Gregory \& Wood 1999, Bernier et al. 2004, Leal et al. 2011) but lower cortisol doses have been shown to stimulate food intake in goldfish (Bernier et al. 2004). Cortisol treatment is able also to regulate the interrenal expression of MC2R (Agulleiro et al. 2013a) suggesting the existence of a negative short-loop feedback that can modulate the sensitivity to ACTH. Central administration of CRF inhibits food intake in several fish species, whereas acute and sustained stressful conditions stimulate CRF expression in the POA/PVN (Bernier 2006). It is therefore conceivable that CRF can mediate the anorectic effects of stress in fish. However, experiments in rainbow trout have shown that exogenous cortisol inhibits preoptic/PVN expression of CRF and NPY but do not prevent the stimulation of neuropeptide expression under stress, suggesting that the responsiveness to acute stressors is maintained under chronic stress (Bernier 2006). This suggests that the fish neural system involved in the control of food intake is responsive to increased plasma cortisol levels but factors other than NPY and CRF mediate the anorexic effects of cortisol in a more significant manner (Doyon et al. 2006). Studies in zebrafish demonstrated that ACTH can bind MC4R in the presence of MRAP2a, a paralogue gene of MRAP1 (Agulleiro et al. 2013b). Peripheral administration of ACTH inhibits food intake in zebrafish, but this effect depends on the presence of a functional MC4R (Agulleiro et al. 2013b). The MC4R is widely expressed in the central feeding centre in fish (Cerdá-Reverter et al. 2003a, Sánchez et al. 2009) and its central signalling seems to be critical in the control of food intake in fish (Cerdá-Reverter \& Peter 2003, Cerdá-Reverter et al. 2003a). Therefore, ACTH binding to MC4R provides a functional substrate for a direct link between the stress axis (ACTH) and the central system controlling food intake (MC4R).

\section{Brain integration and food intake response}

Neuronal populations in ARC respond to a rise in circulating levels of glucose, fatty acid or amino acid with a depolarization (AgRP/NPY neurons) resulting in decreased AgRP and NPY expression, or with a hyperpolarization (CART/POMC neurons) resulting in 
enhanced coexpression of CART and POMC (Schwartz et al. 2000, Levin et al. 2004, Mobbs et al. 2005, Fioramonti et al. 2007). These populations also inhibit each other producing signals to higher-order neurons in PVN, lateral hypothalamus, ventromedial nuclei and dorsomedial nuclei producing neuropeptides like orexin, $\mathrm{MCH}$, thyrotropin-releaseing hormone or corticotropinreleasing hormone (Blouet \& Schwartz 2010, Morton et al. 2014). All these changes ultimately result in changes in food intake.

In fish, NPY and POMC neurons are present in NLTv. These neurons connect to other neurons in NPO and presumably other areas like NLTc, NAT or NLTd whose production of neuropeptides is still not well defined. Aditionally, the position of these nuclei with respect to NLTv differs from that in mammals since some of those nuclei locate outside the hypothalamic area. Neuropeptide expression relates to food intake control since feeding status change mRNA abundance of neuropeptides (Volkoff 2016, Delgado et al. 2017). In brain areas producing NPY and POMC, histochemical studies in rainbow trout support the presence of proteins involved in nutrient sensing such as GK (Polakof et al. 2009) suggesting a functional relationship between nutrient sensing and neuropeptides (Fig. 4). Accordingly, the rise in fish of levels of nutrients like glucose, oleate, octanoate, PUFA or leucine result in general in decreased NPY/AgRP mRNA abundance, increased mRNA abundance of POMC/CART and decreased food intake, whereas the fall in nutrient levels increased NPY/AgRP mRNA abundance, decreased POMC/CART mRNA abundance and increased food intake (Conde-Sieira \& Soengas 2017, Delgado et al. 2017, Comesaña et al. 2018).

The mechanisms linking nutrient-sensing systems with expression of neuropeptides are mostly unknown even in mammals. Changes in the expression of neuropeptides might result from modulation by forkhead boxO1 (FoxO1), phosphorylated cAMP responseelement-binding protein (CREB) and/or brain homeobox transcription factor (BSX) (Diéguez et al. 2011). The actions of these factors would result in the enhancement of CART and POMC expression and the inhibition of AgRP and NPY expression (López et al. 2007, Diéguez et al. 2011). However, it is not clear how transcription factors might relate to nutrient-sensing systems. Several possibilities have been suggested in mammals (López et al. 2007, Diéguez et al. 2011, Gao et al. 2013, Morton et al. 2014, Abdul-Wahed et al. 2017, López 2017) including modulation by malonyl-CoA, CPT-1, AMPK, mTOR, protein kinase B (Akt) or ChREBP. In fish, recent studies carried out in rainbow trout hypothalamus addressed for the first time this topic. The activation of glucosensing (Otero-Rodiño et al. 2017) or fatty acid sensing (Velasco et al. 2017) by glucose, oleate or octanoate resulted in Akt and mTOR activation and AMPK inhibition. Moreover, changes in these proteins would relate to neuropeptide expression through changes in the phosphorylation status of CREB and FoxO1. These results are comparable to those suggested in mammals for glucose and oleate but not for octanoate (Belgardt et al. 2009, Blanco de Morentín et al. 2011, Diéguez et al. 2011). The activation of amino acid-sensing mechanisms by leucine elicited comparable changes in Akt and AMPK but not in transcription factors (Comesaña et al. 2018) thus reflecting the different metabolic importance of amino acid metabolism between fish and mammals. However, the precise mechanisms involved in these mechanisms, as well as the role of BSX still need evaluation.

In mammals, NPY/AgRP and POMC/CART neurons involved in integration of nutrient signals possess receptors for hormones like insulin, leptin, GHRL or CCK among others (Blouet \& Schwartz 2010, Morton et al. 2014). The binding of these hormones elicits changes in molecules involved in intracellular signalling like AMPK, mTOR, etc. Therefore, the final effect on neuropeptide expression results from the joint action of nutrients and hormones on signal transduction. This interaction is characterized in a few cases in mammals, such as the effects of GHRL or leptin on hypothalamic fatty acid-sensing mechanisms (López et al. 2007, Blanco de Morentin et al. 2011). In fish, only a recent study addressed interactive effects of fatty acid-sensing mechanisms and GHRL in rainbow trout hypothalamus (Velasco et al. 2016a) displaying different interactions than those described in mammals. No information is available in fish for other putative interactions between hormones and nutrient-sensing systems. Considering however the effects described for several hormones on glucose (insulin, leptin, ghrelin, GLP-1 or CCK) and fatty acid (GHRL, insulin)-sensing capacity in rainbow trout hypothalamus (Conde-Sieira \& Soengas 2017), the interaction between them on cellular signalling and transcription factors is likely, and might also be different than that characterized in mammals. Figure 8 displays the knowledge regarding integrative pathways in fish and mammals.

\section{Conclusions}

It is important to emphasize that in such heterogeneous group like teleost fish, resulting of millions of years of 
Mammals

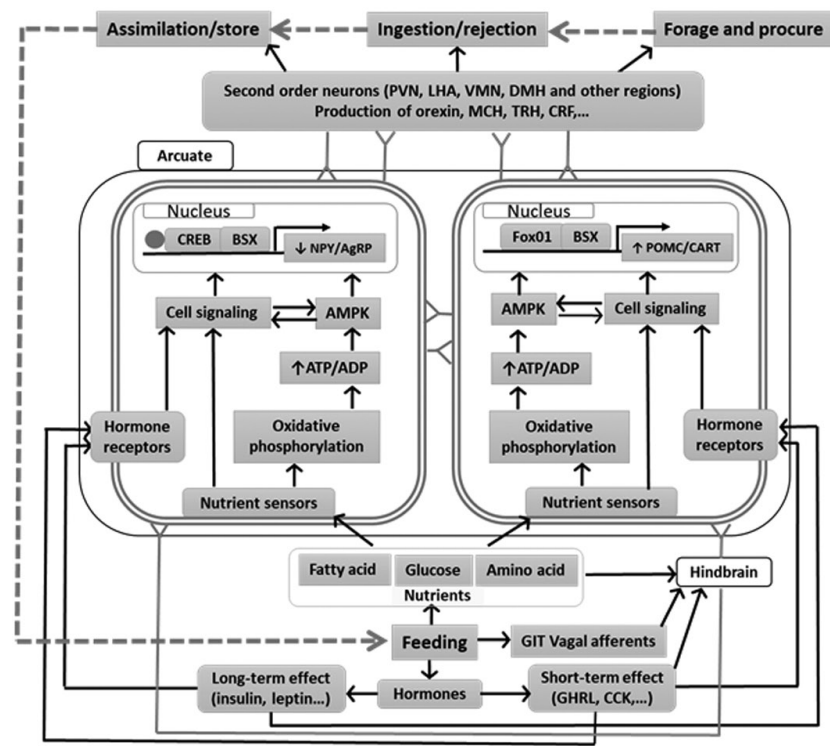

Fish

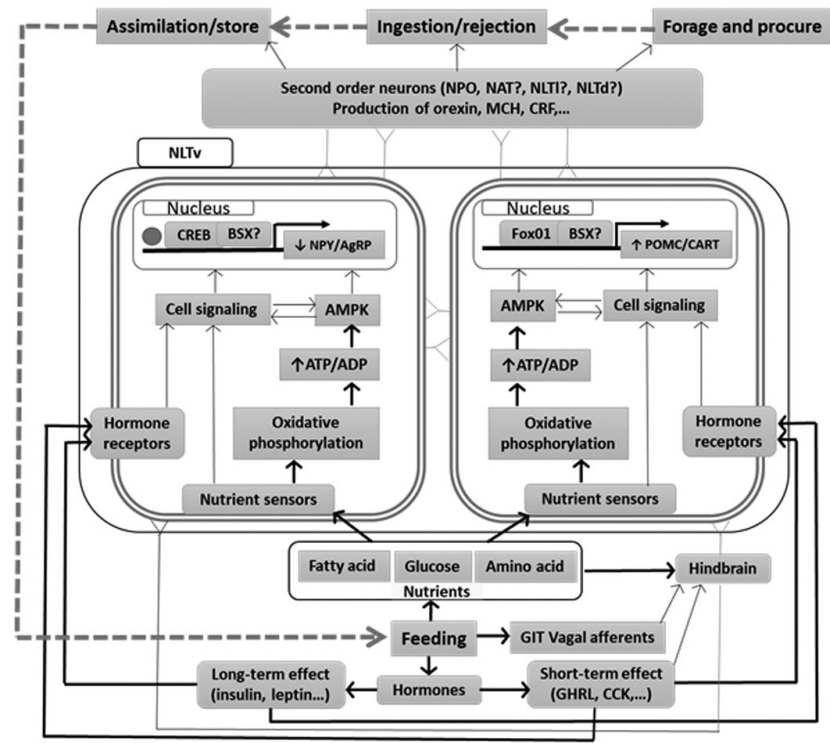

\section{Figure 8}

Schematic drawing with a model of processes involved in central integration of homeostatic control of food intake in mammals and fish. Black thick line, demonstrated relationship; black thin line, partially demonstrated relationship; triangular thick symbols, synaptic connection demonstrated; triangular thin symbols, synaptic connection partially demonstrated; grey dotted line, physiological processes associated with feeding; AgRP, agouti-related peptide; AMP-activated protein kinase; BSX, brain homeobox transcription factor; CART, cocaine- and amphetamine-related transcript; CCK, cholecystokinin; CRF, corticotropin-releasing factor; DMH, dorsal medial hypothalamus; CREB, CAMP response-element-binding protein; FoxO1, forkhead box protein 01; GHRL, ghrelin; GIT, gastrointestinal tract; LHA, lateral hypothalamic area; MCH, melanocyte-concentrating hormone; NAT, anterior tuber nucleus; NLTd, lateral tuber nucleus pars dorsalis; NLTI, lateral tuber nucleus pars lateralis; NLTV, lateral tuber nucleus pars ventralis; NPO, preoptic nuclei; NPY, neuropeptide Y; POMC, pro-opio melanocortin; PVN, paraventricular nuclei; TRH, thyrotropin-releasing hormone; VMN, ventromedial nuclei.

evolution, only several of the groups have been studied in some detail including cypriniformes, pleuronectiformes, salmoniformes and perciformes. The amount of studies in other orders is reduced or simply inexistent. Even in those groups studied in some detail, the existing knowledge refers basically to neuroendocrine signalling. Therefore, it is not possible to suggest clear evolutive trends within teleost fish regarding food intake control. The comparison of two groups of vertebrates separated by millions of years of phylogenetical divergence like teleost fish and mammals displays interesting similarities and differences. The similarities clearly indicate how important regulation of food intake is since most (if not all) mechanisms that emerged in the fish are still present in mammals. These include the presence of specific integrative areas in hypothalamus, the influence of nutrients and hormones and the effects of rhythmicity or stress. The differences can be grouped into two different categories. The first category includes processes relatively well studied in fish for which several differences arise, which might relate to specific fish features regarding anatomy, and hormone and nutrient signalling among others. A second category includes those processes whose information is very limited in fish precluding to elaborate clear hypothesis such as for instance the mechanisms involved in the hedonic control of food intake.

Anatomically, fish brain is different from that of mammals and this clearly includes those areas involved in food intake control. In the homeostatic regulation of food intake is quite probable that nuclei homologous to those present in mammals be present in fish, but their specific locations are rather different. For instance, the connections between fish NLTV (homologous of mammalian ARC) and higher-order neurons presumably differ from those in mammals. These differences might contribute to functional differences in the way nuclei are working together not assessed yet. In the hedonic regulation of food intake, the similarities between brain areas putatively involved (fish telencephalon and mammalian forebrain) are more evident. However, the knowledge regarding their function is very limited. The use of zebrafish as a model in the study of the central nervous system development as well as available genomic tools offer promising opportunities for the use of fish as model in the study of brain homologies.

The hormonal systems involved in the modulation of central control of food intake are basically the same both in teleosts and mammals, suggesting a high degree 
of conservation through vertebrate evolution. The amount of available studies for some hormones in fish is not high enough to carry out proper comparisons, such as the case of glucagon family peptides, insulin or endocannabinoids. In several neuroendocrine systems studied with certain detail in fish, their effects on food intake were in general comparable to those in mammals, such as for NPY, melanocortin system or CCK. However, important differences arise when comparing other relatively well-known hormones in fish such as the case of leptin, orexins, $\mathrm{MCH}$, galanin, CART or GHRL, among others. In some cases, the differences vs mammals are restricted to specific fish taxons but in others attain to all teleosts studied so far. However, teleost additional round(s) of gene duplication might be responsible for some of these differences due to functionalization of additional transcripts, but the differences in GIT function, dietary habits and metabolism are also probably major candidates to explain part of those differences.

The divergent metabolic features between fish and mammals reflect only in several of the mechanisms involved in the control of food intake mediated by nutrient signalling. This is indicative of how important and preserved the homeostatic regulation of food intake is in vertebrates. There are however important differences in nutrient signalling between both groups. Since fish is the most primitive group, it is tempting to speculate that the importance of amino acid-sensing signalling decreased through evolution in favour of a higher importance of glucose signaling, whereas fatty acid sensing would be comparable between groups (with differences related to fatty acid composition). However, the still limited available evidence in fish (especially regarding amino acid sensing) precludes the formulation of clear hypothesis regarding this issue. Furthermore, almost all available studies in nutrient signalling relate to homeostatic regulation of food intake. A possible involvement of these mechanisms in hedonic regulation of food intake is likely, and this will be probably more important again for amino acids (Morais 2017). In this way, preliminary data obtained in rainbow trout suggest that amino acid-sensing systems in rainbow trout telencephalon are involved in reward mechanisms (Comesaña et al. 2018).

The knowledge regarding hypothalamic integration of metabolic, endocrine and circadian information to elicit changes in neuropeptide expression is still limited in fish (Delgado et al. 2017). The few available studies in fish (basically carried out in rainbow trout) pointed to a network comparable to that known in mammals formed by metabolic sensors like AMPK, proteins involved in cellular signalling and transcription factors. However, the precise mechanisms involved, as well as their interaction with hormones modulating food intake, is an open field of research.

As a whole, the still limited information available in fish compared with mammals regarding central control of food intake do not allow us to clearly define evolutionary changes in all aspects concerned, and this also applies to evolutive changes within the teleostean infraclass. In general, the components of mechanisms are basically the same though the way in which they interact is probably different. We can make a simile related to the construction of houses. With the same bricks (components) we can make a house (central control of the intake) but the bricks can be placed in different ways (fish vs mammals). The final result is in both cases a house to live, but it is likely that the appearance of the houses be very different. Ongoing research will provide information about locations and interactions of those bricks.

Declaration of interest

The authors declare that there is no conflict of interest that could be perceived as prejudicing the impartiality of this review.

\section{Funding}

This work did not receive any specific grant from any funding agency in the public, commercial, or not-for-profit sector

\section{Acknowledgements}

The authors acknowledge grants from Spanish Agencia Estatal de Investigación (AEI) and European Fund of Regional Development (FEDER) to J L S (AGL2016-74857-C3-1-R), J M C R (AGL2016-74857-C3-3-R), and M J $D$ (AGL2016-74857-C3-2-R). The authors acknowledge all present and past members of their research groups.

\section{References}

Abdul-Wahed A, Guilmeau S \& Postic C 2017 Sweet sixteenth for ChREBP: established roles and future goals. Cell Metabolism 26 324-341. (https://doi.org/10.1016/j.cmet.2017.07.004)

Acosta-Galvan G, Yia C-X, van der Vlietb J, Jhamandas JH, Panulad P, Angeles-Castellanos M, Basualdoa MC, Escobar C \& Buijs RM 2011 Interaction between hypothalamic dorsomedial nucleus and the suprachiasmatic nucleus determines intensity of food anticipatory behavior. PNAS 108 5813-5818. (https://doi.org/10.1073/ pnas.1015551108)

Agulleiro MJ, Cortés R, Fernández-Durán B, Guillot R, Navarro S, Meimaridou E, Clark AJ \& Cerdá-Reverter JM 2013a Melanocortin 4 receptor becomes an ACTH receptor by coexpression of melanocortin receptor accessory protein 2. Molecular Endocrinology 27 1934-1945. (https://doi.org/10.1210/me.2013-1099)

Agulleiro MJ, Sánchez E, Leal E, Cortés R, Fernández-Durán B, Guillot R, Davis P, Dores RM, Gallo-Payet N \& Cerdá-Reverter JM $2013 b$ 
Molecular characterization and functional regulation of melanocortin receptor type 2 (MC2R) in the sea bass (Dicentrarchus labrax). A putative role in the adaptation to stress. PLOS ONE $\mathbf{8}$ e65450. (https://doi.org/10.1371/journal.pone.0065450)

Agulleiro MJ, Cortés R, Leal E, Ríos D, Sánchez E \& Cerdá-Reverter JM 2014 Characterization, tissue distribution and regulation by fasting of the agouti family of peptides in the sea bass (Dicentrarchus labrax). General and Comparative Endocrinology 205 251-259. (https://doi. org/10.1016/j.ygcen.2014.02.009)

Ahima RS 2006 Adipose tissue as an endocrine organ. Obesity 14 242S-249S. (https://doi.org/10.1038/oby.2006.317)

Akash G, Kaniganti T, Tiwari NK, Subhedar NK \& Ghose A 2014 Differential distribution and energy status-dependent regulation of the four CART neuropeptide genes in the zebrafish brain. Journal of Comparative Neurology 522 2266-2285. (https://doi.org/10.1002/cne.23532)

Aranda A, Madrid JA \& Sánchez-Vázquez FJ 2001 Influence of light on feeding anticipatory activity in goldfish. Journal of Biological Rhythm 6 50-57. (https://doi.org/10.1177/074873040101600106)

Attia J, Millot S, Di-Poï C, Bégout M-L, Noble C, Sanchez-Vazquez FJ, Terova G, Saroglia M \& Damsgård B 2012 Demand feeding and welfare in farmed fish. Fish Physiology and Biochemistry 38 107-118. (https://doi.org/10.1007/s10695-011-9538-4)

Bae S-A \& Androulakis IP 2017 The synergistic role of light-feeding phase relations on entraining robust circadian rhythms in the periphery. Gene Regulation and Systems Biology 11 1-21. (https://doi. org/10.1177/1177625017702393)

Balasubramanian MN, Panserat S, Dupont-Nivet M, Quillet E, Montfort J, Le Cam A, Medale F, Kaushik S \& Geurden I 2016 Molecular pathways associated with the nutritional programming of plant-based diet acceptance in rainbow trout following an early feeding exposure. BMC Genomics 17 449. (https://doi.org/10.1186/s12864-016-2804-1)

Bangol D, Lu X-Y, Kaelin CB, Day HEW, Ollmann M, Gantz I, Akil H, Barsh GS \& Watson SJ 1999 Anatomy of an endogenous antagonist: relationship between agouti-related protein and proopiomelanocortin in the brain. Journal of Neuroscience 19 RC26.

Beall C, Piipari K, Al-Qassab H, Smith MA, Parker N, Carling D, Viollet B, Withers DJ \& Ashford MLJ 2010 Loss of AMP-activated protein kinase a2 subunit in mouse b-cells impairs glucosestimulated insulin secretion and inhibits their sensitivity to hypoglycaemia. Biochemical Journal 429 323-333. (https://doi. org/10.1042/BJ20100231)

Beinfeld MC 1983 Cholecystokinin in the central nervous system: a minireview. Neuropeptides 3 411-427. (https://doi.org/10.1016/01434179(83)90032-X)

Belgardt BF, Okamura T \& Brüning JC 2009 Hormone and glucose signalling in POMC and AgRP neurons. Journal of Physiology $\mathbf{5 8 7}$ 5305-5314. (https://doi.org/10.1113/jphysiol.2009.179192)

Bell ME, Bhatnagar S, Akana SF, Choi S \& Dallman MF 2000 Disruption of arcuate/paraventricular nucleus connections changes body energy balance and response to acute stress. Journal of Neuroscience $\mathbf{2 0}$ 6707-6713.

Bernier NJ 2006 The corticotrophin-releasing factor system as mediator of the appetite-suppressing effects of stress in fish. General and Comparative Endocrinology 146 45-55. (https://doi.org/10.1016/j. ygcen.2005.11.016)

Bernier NJ, Bedard N \& Peter RE 2004 Effects of cortisol on food intake, growth, and forebrain neuropeptide $\mathrm{Y}$ and corticotropin releasing factor gene expression in goldfish. General and Comparative Endocrinology 135 230-240. (https://doi.org/10.1016/j. ygcen.2003.09.016)

Berthoud HR 2002 Multiple neural systems controlling food intake and body weight. Neuroscience Biobehavioral Reviews 26 393-428. (https:// doi.org/10.1016/S0149-7634(02)00014-3)

Berthoud H-R \& Morrison C 2008 The brain, appetite, and obesity. Annual Review of Psychology 59 55-92. (https://doi.org/10.1146/ annurev.psych.59.103006.093551)
Betancur R, Broughton RE, Wiley EO, Carpenter K, López JA, Li C, Holcroft NI, Arcila D, Sanciangco M, Cureton JC II, et al. 2013 The tree of life and a new classification of bony fishes. PLoS Currents Tree of Life. (https://doi.org/10.1371/currents.tol.53ba26640df0ccaee75bb $165 \mathrm{c} 8 \mathrm{c} 26288)$

Biechl D, Tietje K, Ryu S, Grothe B, Gerlach G \& Wullimann MF 2017 Identification of accessory olfactory system and medial amygdala in the zebrafish. Scientific Reports 7 44295. (https://doi.org/10.1038/ srep44295)

Blanco AM, Gómez-Boronat M, Redondo I, Valenciano AI \& Delgado MJ 2016 Periprandial changes and effects of short- and long-term fasting on ghrelin, GOAT, and ghrelin receptors in goldfish (Carassius auratus). Journal of Comparative Physiology B 186 727-738. (https://doi.org/10.1007/s00360-016-0986-0)

Blanco AM, Bertucci JI, Valenciano AI, Delgado MJ \& Unniappan S 2017 Ghrelin suppresses cholecystokinin (CCK), peptide YY (PYY) and glucagon-like peptide-1 (GLP-1) in the intestine, and attenuates the anorectic effects of CCK, PYY and GLP-1 in goldfish (Carassius auratus). Hormones and Behavior 93 62-71. (https://doi.org/10.1016/j. yhbeh.2017.05.004)

Blanco de Morentin PB, González CR, Saha AK, Martins L, Diéguez C, Vidal-Puig A, Tena-Sempere M \& López M 2011 Hypothalamic AMPactivated protein kinase as a mediator of whole body energy balance. Reviews of Endocrine Metabolic Disorders 12 127-140. (https://doi. org/10.1007/s11154-011-9165-5)

Blasiak A, Gundlach AL, Hess G \& Lewandowski MH 2017 Interactions of circadian rhythmicity, stress and orexigenic neuropeptide systems: implications for food intake control. Frontiers in Neuroscience 11127. (https://doi.org/10.3389/fnins.2017.00127)

Blomqvist AG, Söderberg C, Lundell I, Milner RJ \& Larhammar D 1992 Strong evolutionary conservation of neuropeptide Y: sequences of chicken, goldfish, and Torpedo marmorata DNA clones. PNAS 89 2350-2354. (https://doi.org/10.1073/pnas.89.6.2350)

Blouet C \& Schwartz GJ 2010 Hypothalamic nutrient sensing in the control of energy homeostasis. Behavioral Brain Research 209 1-12. (https://doi.org/10.1016/j.bbr.2009.12.024)

Blouet C \& Schwartz GJ 2012 Brainstem nutrient sensing in the nucleus of the solitary tract inhibits feeding. Cell Metabolism 16 579-587. (https://doi.org/10.1016/j.cmet.2012.10.003)

Blouet C, Mariotti F, Azzout-Marniche D, Bos C, Mathe V, Tome D \& Huneau JF 2006 The reduced energey intake of rats fed a highprotein low-carbohydrate diets explains the lower fat deposition, but macronutrient substitution accounts for the improved glycemic control. Journal of Nutrition 136 1849-1854. (https://doi.org/10.1093/ jn/136.7.1849)

Blum ID, Waddington Lamont E \& Abizaid A 2012 Competing clocks: metabolic status moderates signals from the master circadian pacemaker. Neuroscience and Biobehavioral Reviews 36 254-270. (https://doi.org/10.1016/j.neubiorev.2011.06.003)

Bonacic K, Campoverde C, Gómez-Arbones J, Gisbert E, Estevez A \& Morais S 2016 Dietary fatty acid composition affects food intake and gut-brain satiety signaling in Senegalese sole (Solea senegalensis, Kaup 1858) larvae and post-larvae. General and Comparative Endocrinology 228 79-94. (https://doi.org/10.1016/j.ygcen.2016.02.002)

Boujard T, Labbe L \& Auperin B 2002 Feeding behaviour, energy expenditure and growth in rainbow trout in relation to stocking density and food accessibility. Aquaculture Research 33 1233-1242. (https://doi.org/10.1046/j.1365-2109.2002.00755.x)

Bouret SG, Draper SJ \& Simerly RB 2004 Formation of projection pathways from the arcuate nucleus of the hypothalamus to hypothalamic regions implicated in the neural control of feeding behavior in mice. Journal of Neuroscience 24 2797-2805. (https://doi. org/10.1523/JNEUROSCI.5369-03.2004)

Bshary R, Gingins S \& Vail AL 2014 Social cognition in fishes. Trends in Cognitive Science 18 465-471. (https://doi.org/10.1016/j. tics.2014.04.005) 
Cal L, Suarez-Bregua P, Cerdá-Reverter JM, Braasch I \& Rotllant J 2017 Fish pigmentation and the melanocortin system. Comparative Biochemistry and Physiology A 211 26-33. (https://doi.org/10.1016/j. cbpa.2017.06.001)

Capilla E, Médale F, Navarro I, Panserat S, Vachot C, Kaushik S \& Gutiérrez J 2003 Muscle insulin binding and plasma levels in relation to liver glucokinase activity, glucose metabolism and dietary carbohydrates in rainbow trout. Regulatory Peptides 110 123-132. (https://doi.org/10.1016/S0167-0115(02)00212-4)

Carneiro BTS \& Araujo JF 2012 Food entrainment: major and recent findings. Frontiers in Behavioral Neuroscience 6 83. (https://doi. org/10.3389/fnbeh.2012.00083)

Castro C, Corraze G, Pérez-Jimenez A, Larroquet L, Cluzeaud M, Panserat S \& Oliva-Teles A 2015 Dietary carbohydrate and lipid source affect cholesterol metabolism of European sea bass (Dicentrarchus labrax) juveniles. British Journal of Nutrition 114 1584-1593. (https://doi.org/10.1017/S0007114515003360)

Cavanaugh AR, Schwartz GJ \& Blouet C 2015 High-fat feeding impairs nutrient sensing and gut bran integration in the caudomedial nucleus of the solitary tract in mice. PLOS ONE 10 e0118888. (https://doi.org/10.1371/journal.pone.0118888)

Cerdá-Reverter JM \& Canosa LF 2009 Neuroendocrine systems of the fish brain. In Fish Neuroendocrinology, pp 3-74. Eds NJ Bernier, GJ Van der Kraak, AP Farrell \& CJ Brauner. Amsterdam: Elsevier.

Cerdá-Reverter JM \& Larhammar D 2000 Neuropeptide Y family of peptides: structure, anatomical expression, function and molecular evolution. Biochemistry and Cell Biology 78 371-392.

Cerdá-Reverter JM \& Peter RE 2003 Endogenous melanocortin antagonist in fish. Structure, brain mapping and regulation by fasting of the goldfish agouti-related protein gene. Endocrinology $\mathbf{1 4 4}$ 4552-4561.

Cerdá-Reverter JM, Anglade I, Martínez-Rodríguez G, Mazurais D, Muñoz-Cueto JA, Carrillo M, Kah O \& Zanuy S 2000a Characterization of neuropeptide $\mathrm{Y}$ expression in the brain of a perciform fish, the sea bass (Dicentrarchus labrax). Journal of Chemical Neuroanatomy 19 197-210.

Cerdá-Reverter JM, Martínez-Rodríguez G, Anglade I, Kah O \& Zanuy S $2000 b$ Peptide YY (PYY) and fish pancreatic peptide Y (PY) expression in the brain of the sea bass (Dicentrarchus labrax) as revealed by in situ hybridization. Journal of Comparative Neurology 426 197-208.

Cerdá-Reverter JM, Ringholm A, Schiöth HB \& Peter RE 2003a Molecular cloning, pharmacological characterization and brain mapping of the melanocortin 4 receptor in the goldfish: involvement in the control of food intake. Endocrinology 144 2336-2349.

Cerdá-Reverter JM, Schiöth HB \& Peter RE 2003b The central melanocortin system regulates food intake in goldfish. Regulatory Peptides 115 101-113.

Cerdá-Reverter JM, Agulleiro MJ, Guillot R, Sánchez E, Ceinos R \& Rotlant J 2011 Fish melanocortin system. European Journal of Pharmacology 660 53-60. (https://doi.org/10.1016/j.ejphar.2010.10.108)

Cerdá-Reverter JM, Agulleiro, MJ, Cortés R, Sánchez E, Guillot R, Leal E, Fernández-Durán B, Puchol S \& Eley M 2013 Involvement of MRAPs in the function of melanocortin receptors (MCRs). General and Comparative Endocrinology 188 133-136.

Chartrel N, Tsutsui K, Costentin J \& Vaudry H 2006 The RF amiderelated peptides. In Handbook of Biologically Active Peptides, pp 779-786. Ed AJ Kastin. San Diego: Academic press.

Chartrel N, Alonzeau J, Alexandre D, Jeandel L, Alvear-Perez R, Leprince J, Boutin J, Vaudry H, Anouar Y \& Llorens-Cortes C 2011 The RFamide neuropeptide 26RFa and its role in the control of neuroendocrine functions Frontiers in Neuroendocrinology 32 387-397. (https://doi.org/10.1016/j.yfrne.2011.04.001)

Comesaña S, Velasco C, Ceinos RM, López-Patiño M, Míguez JM, Morais S \& Soengas JL 2018 Evidence for the presence in rainbow trout brain of amino acid sensing systems involved in the control of food intake. American Journal of Physiology: Regulatory, Integrative and Comparative Physiology 314 R201-R215. (https://doi.org/10.1152/ ajpregu.00283.2017)

Conde-Sieira M \& Soengas JL 2017 Nutrient sensing systems in fish: impact on food intake regulation and energy homeostasis. Frontiers in Neuroscience 10 603. (https://doi.org/10.3389/fnins.2016.00603)

Conde-Sieira M, Aguilar AJ, López-Patiño MA, Míguez JM \& Soengas JL $2010 a$ Stress alters food intake and glucosensing response in hypothalamus, hindbrain, liver, and Brockmann bodies of rainbow trout. Physiology and Behavior 101 483-493. (https://doi. org/10.1016/j.physbeh.2010.07.016)

Conde-Sieira M, Agulleiro MJ, Aguilar AJ, Míguez JM, Cerdá-Reverter JM \& Soengas JL $2010 b$ Effect of different glycaemic conditions on gene expression of neuropeptides involved in control of food intake in rainbow trout; interaction with stress. Journal of Experimental Biology 213 3858-3865. (https://doi.org/10.1242/jeb.048439)

Conde-Sieira M, López-Patiño MA, Míguez JM \& Soengas JL 2012 Glucosensing capacity in rainbow trout liver displays day-night variations possibly related to melatonin action. Journal of Experimental Biology 215 3112-3119. (https://doi.org/10.1242/ jeb.069740)

Conde-Sieira M, Bonacic K, Velasco C, Valente LMP, Morais S \& Soengas JL 2015 Hypothalamic fatty acid sensing in Senegalese sole (Solea senegalensis): response to long-chain saturated, monounsaturated, and polyunsaturated (n-3) fatty acids. American Journal of Physiology: Regulatory, Integrative and Comparative Physiology 309 R1521-R1531. (https://doi.org/10.1152/ajpregu.00386.2015)

Copeland DL, Duff RJ, Liu Q, Prokop J \& Londraville RL 2011 Leptin in teleost fishes: an argument for comparative study. Frontiers in Physiology 2 26. (https://doi.org/10.3389/fphys.2011.00026)

Cowan M, Azpeleta C \& López-Olmeda JF 2017 Rhythms in the endocrine system of fish: a review. Journal of Comparative Physiology B 187 1057-1089. (https://doi.org/10.1007/s00360-017-1094-5)

Cowley MA, Smart JL, Rubinstein M, Cerdán MG, Diano S, Horvath TH, Cone RD \& Low MJ 2001 Leptin activates anorexigenic POMC neurons through a neural network in the arcuate nucleus. Nature 411 480-484. (https://doi.org/10.1038/35078085)

Cummings DE \& Overduin J 2007 Gastrointestinal regulation of food intake. Journal of Clinical Investigation 117 13-23. (https://doi. org/10.1172/JCI30227)

Dai W, Panserat S, Kaushik S, Terrier F, Plagnes-Juan E, Seiliez I \& SkibaCassy S 2016 Hepatic fatty acid biosynthesis is more responsive to protein than carbohydrate in rainbow trout during acute stimulations. American Journal of Physiology: Regulatory, Integrative and Comparative Physiology 310 R74-R86. (https://doi.org/10.1152/ ajpregu.00281.2015)

Dalmolin C, Almeida DV, Figueiredo MA \& Marins LF 2015 Food intake and appetite control in a GH-transgenic zebrafish. Fish Physiology and Biochemistry 41 1131-1141. (https://doi.org/10.1007/s10695-0150074-5)

Davis DA, Lazo JP \& Arnold CR 1999 Response of juvenile red drum (Sciaenops ocellatus) to practical diets supplemented with medium chain triglycerides. Fish Physiology and Biochemistry 21 235-247. (https://doi.org/10.1023/A:1007836612376)

Day RD, German DP, Manjakasy JM, Farr I, Hansen MJ \& Tibbetts IR 2011 Enzymatic digestión in stomachless fishes: how a simple gut accommodates both herbivory and carnivory. Journal of Comparative Physiology B 181 603-613. (https://doi.org/10.1007/s00360-0100546-y)

Deck CA, Honeycutt JL, Cheung E, Reynolds HM \& Borski RJ 2017 Assessing the functional role of leptin in energy homeostasis and the stress response in vertebrates. Frontiers in Endocrinology 8 63. (https:// doi.org/10.3389/fendo.2017.00063)

Delezie J, Dumont S, Sandu C, Reibel S, Pevet P \& Challet E 2016 Reverb $\alpha$ in the brain is essential for circadian food entrainment. Scientific Reports 6 29386. (https://doi.org/10.1038/srep29386) 
Delgado MJ, Cerdá-Reverter JM \& Soengas JL 2017 Hypothalamic integration of metabolic, endocrine, and circadian signals in fish: involvement in the control of food intake. Frontiers in Neuroscience 11 354. (https://doi.org/10.3389/fnins.2017.00354)

Demski LS 2012 The neural control of feeding in elasmobranchs: a review and working model. Environmental Biology of Fish 95 169-183. (https://doi.org/10.1007/s10641-011-9827-x)

Demski LS \& Knigge KM 1971 The telencephalon and hypothalamus of bluegill (Lepomis macrochirus): evoked feeding, aggressive and reproductive behavior with representative frontal sections. Journal of Comparative Neurology 143 1-16. (https://doi.org/10.1002/ cne.901430102)

de Araujo LD, Roa SL, Bueno AC, Coeli-Lacchini FB, Martins CS, Uchoa ET, Antunes-Rodrigues J, Elias LL, Elias PC, Moreira AC, et al. 2016 Restricted feeding schedules modulate in a different manner the expression of clock genes in rat hypothalamic nuclei. Frontiers in Neuroscience 10 567. (https://doi.org/10.3389/fnins.2016.00567)

de Pedro N, Delgado MJ \& Alonso-Bedate M 1995a Central administration of beta-endorphin increases food intake in goldfish: pretreatment with the opioid antagonist naloxone. Regulatory Peptides 55 189-195. (https://doi.org/10.1016/0167-0115(95)92305-V)

de Pedro N, Céspedes MV, Delgado MJ \& Alonso-Bedate M 1995b The galanin-induced feeding stimulation is mediated via $\alpha 2$-adrenergic receptors in goldfish. Regulatory Peptides 57 77-84. (https://doi. org/10.1016/0167-0115(95)91255-4)

de Pedro N, Delgado MJ, Pinillos ML \& Alonso-Bedate M 1998 Alpha1adrenergic and dopaminergic receptors are involved in the anoretic effect of corticotropin-releasing factor in goldfish. Life Sciences $\mathbf{6 2}$ 1801-1808. (https://doi.org/10.1016/S0024-3205(98)00142-8)

de Pedro N, López Patiño MA, Guijarro AI, Pinillos ML, Delgado MJ \& Alonso-Bedate M 2000 NPY receptors and opioidergic system are involved in NPY-induced feeding in goldfish. Peptides 21 1495-1502. (https://doi.org/10.1016/S0196-9781(00)00303-X)

de Pedro N, Martínez-Álvarez R \& Delgado MJ 2006 Acute and chronic leptin reduces food intake and body weight in goldfish (Carassius auratus). Journal of Endocrinology 188 513-520. (https://doi. $\operatorname{org} / 10.1677 /$ joe.1.06349)

Diano S \& Horvath K 2012 Mitochondrial uncoupling protein 2 (UCP2) in glucose and lipid metabolism. Trends in Molecular Medicine $\mathbf{1 8}$ 52-58. (https://doi.org/10.1016/j.molmed.2011.08.003)

Diéguez C, Vazquez MJ, Romero A, López M \& Nogueiras R 2011 Hypothalamic control of lipid metabolism: focus on leptin, ghrelin and melanocortins. Neuroendocrinology 94 1-11. (https://doi. org/10.1159/000328122)

Doyon C, Leclair J, Trudeau VL \& Moon TW 2006 Corticotropinreleasing factor and neuropeptide Y mRNA levels are modified by glucocorticoids in rainbow trout, Oncorhynchus mykiss. General and Comparative Endocrinology 146 126-135. (https://doi.org/10.1016/j. ygcen.2005.10.003)

Duan Y, Li F, Li Y, Tang Y, Kong X, Feng Z, Anthony TG, Watford M, Hou Y, Wu G \& Yin Y 2016 The role of leucine and its metabolites in protein and energy metabolites in protein and energy metabolism. Amino Acids 48 41-51. (https://doi.org/10.1007/s00726015-2067-1)

Efeyan A, Comb WC \& Sabatini DM 2015 Nutrient sensing mechanisms and pathways. Nature 517 302-310. (https://doi.org/10.1038/ nature14190)

Elias CF, Lee C, Kelly J, Aschkenasi C, Ahima RS, Couceyro PR, Kuhar MJ, Saper CB \& Elmquist JK 1989 Leptin activates hypothalamic CART neurons projecting to the spinal cord. Neuron 21 1375-1385. (https://doi.org/10.1016/S0896-6273(00)80656-X)

Eva C, Serra M, Mele P, Panzica G \& Oberto A 2006 Physiology and gene regulation of the brain NPY Y1 receptor Frontiers in Neuroendocrinology 27 308-339. (https://doi.org/10.1016/j. yfrne.2006.07.002)
Everett LJ \& Lazar MA 2014 Nuclear receptor Rev-erba: up, down, and all around. Trends in Endocrinology and Metabolism 25 586-592. (https://doi.org/10.1016/j.tem.2014.06.011)

Feillet CA, Albrecht U \& Challet E 2006 'Feeding time' for the brain: a matter of clocks. Journal of Physiology 100 252-260. (https://doi. org/10.1016/j.jphysparis.2007.05.002)

Feillet CA, Bainier C, Mateo M, Blancas-Velázquez A, Salaberry NL, Ripperger JA, Albrecht U \& Mendoza J 2017 Rev-erb $\alpha$ modulates the hypothalamic orexinergic system to influence pleasurable feeding behaviour in mice. Addiction Biology 22 411-422. (https://doi. org/10.1111/adb.12339)

Feliciano A, Vivas Y, De Pedro N, Delgado MJ, Velarde E \& Isorna E 2011 Feeding time synchronizes clock gene rhythmic expression in brain and liver of goldfish (Carassius auratus). Journal of Biological Rhythms 26 24-33. (https://doi.org/10.1177/0748730410388600)

Fetissov SO 2017 Role of the gut microbiota in host appetite control: bacterial growth to animal feeding behaviour. Nature Reviews Endocrinology 13 11-25. (https://doi.org/10.1038/nrendo.2016.150)

Figueiredo-Silva A, Kaushik S, Terrier F, Schrama JW, Médale F \& Geurden I $2012 a$ Link between lipid metabolism and voluntary food intake in rainbow trout fed coconut oil rich in medium-chain TAG. British Journal of Nutrition 107 1714-1725. (https://doi.org/10.1017/ S0007114511004739)

Figueiredo-Silva AC, Saravanan S, Schrama JW, Kaushik S \& Geurden I $2012 b$ Macronutrient-induced differences in food intake relate with hepatic oxidative metabolism and hypothalamic regulatory neuropeptides in rainbow trout (Oncorhynchus mykiss). Physiology and Behavior 106 499-505. (https://doi.org/10.1016/j. physbeh.2012.03.027)

Figueiredo-Silva AC, Saravanan S, Schrama JW, Panserat S, Kaushik S \& Geurden I 2013 A comparative study of the metabolic response in rainbow trout and Nile tilapia to changes in dietary macronutrient composition. British Journal of Nutrition 109 816-826. (https://doi. org/10.1017/S000711451200205X)

Fioramonti X, Contié S, Song Z, Routh VH, Lorsignol A \& Pénicaud L 2007 Characterization of glucosensing neuron subpopulations in the arcuate nucleus. Integration in neuropeptide $\mathrm{Y}$ and pro-opio melanocortin networs? Diabetes 56 1219-1227. (https://doi. org/10.2337/db06-0567)

Forlano PM \& Cone RD 2007 Conserved neurochemical pathways involved in hypothalamic control of energy homeostasis. Journal of Comparative Neurology 505 235-248. (https://doi.org/10.1002/cne.21447)

Friedman J 2014 Leptin at 20: an overview. Journal of Endocrinology 223 T1-T8. (https://doi.org/10.1530/JOE-14-0405)

Fromentin G, Darcel N, Chaumontet C, Marsset-Baglieri A, Nadkarni N \& Tom D 2012 Peripheral and central mechanisms involved in the control of food intake by dietary amino acids and proteins. Nutritional Research Reviews 25 29-39. (https://doi.org/10.1017/ S0954422411000175)

Fu J, Gaetani S, Oveisi F, Lo Verme J, Serrano A, Rodríguez De Fonseca F, Rosengarth A, Luecke H, Di Giacomo B, Tarzia G, et al. 2003 Oleylethanolamide regulates feeding and body weight through activation of the nuclear receptor PPAR-alpha. Nature 425 90-93. (https://doi.org/10.1038/nature01921)

Gaetani S, Oveisi F \& Piomelli D 2003 Modulation of meal pattern in the rat by the anorexic lipid mediator oleoylethanolamide. Neuropsychopharmacology 28 1311-1316. (https://doi.org/10.1038/sj. npp.1300166)

Ganz J, Kaslin J, Freudenreich D, Machate A, Geffarth M \& Brand M 2012 Subdivisions of the adult zebrafish subpallium by molecular marker analysis. Journal of Comparative Neurology 520 633-655. (https://doi.org/10.1002/cne.22757)

Ganz J, Kroehne V, Freudenreich D, Machate A, Geffarth M, Braasch I, Kaslin J \& Brand M 2014 Subdivisions of the adult zebrafish pallium based on molecular marker analysis. F1000 Research 3 1-20. 
Gao S, Moran TH, Lopaschuk GD \& Butler AA 2013 Hypothalamic malonyl-CoA and the control of food intake. Physiology and Behavior 122 17-24. (https://doi.org/10.1016/j.physbeh.2013.07.014)

Gerking SD 1994 Feeding Ecology of Fish. New York: Academic Press.

Geurden I, Corraze G \& Boujard T 2007 Self-feeding behaviour of rainbow trout, Oncorhynchus mykiss, offered diets with distinct feed oils. Applied Animal Behaviour Science 108 313-326. (https://doi. org/10.1016/j.applanim.2006.12.006)

Ghamari-Langroudi M, Srisai D \& Cone RD 2011 Multinodal regulation of the arcuate/paraventricular nucleus circuit by leptin. PNAS $\mathbf{1 0 8}$ 355-360. (https://doi.org/10.1073/pnas.1016785108)

Gong Y, Chen W, Han D, Zhu X, Yang Y, Jin J, Liu H \& Xie S 2017 Effects of food restriction on growth, body composition and gene expression related in regulation of lipid metabolism and food intake in grass carp. Aquaculture 469 28-35. (https://doi.org/10.1016/j. aquaculture.2016.12.003)

Gómez-Boronat M, Velasco C, Isorna E, De Pedro N, Delgado MJ \& Soengas JL 2016 The satiety factor oleoylethanolamide impacts hepatic lipid and glucose metabolism in goldfish. Journal of Comparative Physiology B 186 1009-1021. (https://doi.org/10.1007/ s00360-016-1009-x)

González JA, Reimann F \& Burdakov D 2009 Dissociation between sensing and metabolism of glucose in sugar sensing neurones. Journal of Physiology 587 41-48. (https://doi.org/10.1113/jphysiol.2008.163410)

Goodson JL \& Kingsbury MA 2013 What's in a name? Considerations of homologies and nomenclature for vertebrate social behavior networks. Hormones and Behavior 64 103-112. (https://doi. org/10.1016/j.yhbeh.2013.05.006)

Gorissen M, Bernier NJ, Nabuurs SB, Flik G \& Huising MO 2009 Two divergent leptin paralogues in zebrafish (Danio rerio) that originate early in teleostean evolution. Journal of Endocrinology 201 329-339. (https://doi.org/10.1677/JOE-09-0034)

Greco JA, Oosterman JE \& Belsham DD 2014 Differential effects of omega-3 fatty acid docosahexanoic acid and palmitate on the circadian transcriptional profile of clock genes in immortalized hypothalamic neurons. American Journal of Physiology: Regulatory, Integrative and Comparative Physiology 307 R1049-R1060. (https://doi. org/10.1152/ajpregu.00100.2014)

Gregory TR \& Wood CM 1999 The effects of chronic plasma cortisol elevation on the feeding behaviour, growth, competitive ability, and swimming performance of juvenile rainbow trout. Physiological and Biochemical Zoology 72 286-295. (https://doi.org/10.1086/316673)

Guijarro AI, Delgado MJ, Pinillos ML, López MA, Alonso-Bedate M \& de Pedro N 1999 Galanin and $\beta$-endorphin as feeding regulators in cyprinids: effect of temperatura. Aquaculture Research 3 483-489. (https://doi.org/10.1046/j.1365-2109.1999.00360.x)

Guillot R, Cortés R, Navarro S, Mischitelli M, García-Herranz V, Sánchez E, Cal L, Navarro JC, Míguez JM, Afanasyev S, et al. 2016 Behind melanocortin antagonist overexpression in the zebrafish brain: a behavioral and transcriptomic approach. Hormones and Behavior 82 87-100. (https://doi.org/10.1016/j.yhbeh.2016.04.011)

Hahn TM, Breininger JF, Baskin DG \& Schwartz MW 1998 Coexpression of Agrp and NPY in fasting-activated hypothalamic neurons. Nature Neuroscience 1 271-272. (https://doi.org/10.1038/1082)

Havel PJ 2001 Peripheral signals conveying metabolic information to the brain: short-term and long-term regulation of food intake and energy homeostasis. Experimental Biology and Medicine 226 963-977. (https://doi.org/10.1177/153537020122601102)

Heeley N \& Blouet C 2016 Central amino acid sensing in the control of feeding behavior. Frontiers in Endocrinology 7148.

Heisler LK \& Lam DD 2017 An appetite for life: brain regulation of hunger and satiety. Current Opinion in Pharmacology 37 100-106. (https://doi.org/10.1016/j.coph.2017.09.002)

Herget U \& Ryu S 2015 Coexpression analysis of nine neuropeptides in the neurosecretory preoptic area of larval zebrafish. Frontiers in Neuroanatomy 129
Herget U, Wolf A, Wullimann MF \& Ryu S 2014 Molecular neuroanatomy and chemoarchitecture of the neurosecretory preoptic-hypothalamic area in zebrafish larvae. Journal of Comparative Neurology 522 1542-1564. (https://doi.org/10.1002/cne.23480)

Herrera Moro Chao D, Argmann C, Van Eijk M, Boot RG, Ottenhoff R, Van Roomen C, Foppen E, Siljee JE, Unmehopa UA, Kalsbeek A, et al. 2016 Impact of obesity on taste receptor expression in extra-oral tissues: emphasis on hypothalamus and brainstem. Scientific Reports 6 29094. (https://doi.org/10.1038/srep29094)

Hewagalamulage SD, Lee TK, Clarke IJ \& Henry BA 2016 Stress, cortisol, and obesity: a role for cortisol responsiveness in identifying individuals prone to obesity. Domestic Animal Endocrinology 56 S112-S120. (https://doi.org/10.1016/j.domaniend.2016.03.004)

Himick BA \& Peter RE 1994 CCK/gastrin-like immunoreactivity in brain and gut, and CCK suppression of feeding in goldfish. American Journal of Physiology: Regulatory, Integrative and Comparative Physiology 267 R841-R851. (https://doi.org/10.1152/ajpregu.1994.267.3.R841)

Hnasko TS, Perez FA, Scouras AD, Stoll EA, Gale SD, Luquet S, Phillips PE, Kremer EJ \& Palmiter RD 2006 Cre recombinasemediated restoration of nigrostriatal dopamine in dopaminedeficient mice reverses hypophagia and bradykinesia. PNAS 103 8858-8863. (https://doi.org/10.1073/pnas.0603081103)

Horvath TL, Bechmann I, Naftolin F, Kalra SP \& Leranth C 1997 Heterogeneity in the neuropeptide Y-containing neurons of the rat arcuate nucleus: GABAergic and non-GABAergic subpopulations. Brain Research 756 283-286. (https://doi.org/10.1016/S00068993(97)00184-4)

Hoskins LJ \& Volkoff H 2012 The comparative endocrinology of feeding in fish: insights and challenges. General and Comparative Endocrinology 176 327-335. (https://doi.org/10.1016/j. ygcen.2011.12.025)

Hu F, Xu Y \& Liu F 2016 Hypothalamic roles of mTOR complex I: integration of nutrient and hormone signals to regulate energy homeostasis. American Journal of Physiology: Endocrinology and Metabolism 310 E994-E1002. (https://doi.org/10.1152/ ajpendo.00121.2016)

Hu Z, Cha SH, Chohnan S \& Lane MD 2011 Hypothalamic malonylCoA as a mediator of feeding behavior. PNAS 100 12624-12629. (https://doi.org/10.1073/pnas.1834402100)

Hunter RG, Philpot K, Vicentic A, Dominguez G, Hubert GW \& Kuhar MJ 2004 CART in feeding and obesity. Trends in Endocrinology and Metabolism 15 454-459. (https://doi.org/10.1016/j. tem.2004.09.010)

Hussain Z \& Khan JA 2017 Food intake regulation by leptin: mechanisms mediating gluconeogenesis and energy expenditure. Asian Pacific Journal of Tropical Medicine 10 940-944. (https://doi. org/10.1016/j.apjtm.2017.09.003)

Isorna E, de Pedro N, Valenciano AI, Alonso-Gómez AL \& Delgado MJ 2017 Interplay between the endocrine and circadian systems in fishes. Journal of Endocrinology 232 R141-R159. (https://doi. org/10.1530/JOE-16-0330)

Jewell J \& Guan K 2013 Nutrient signaling to mTOR and cell growth. Trends in Biochemical Science 38 233-242. (https://doi.org/10.1016/j. tibs.2013.01.004)

Ji W, Ping H-C, Wei K-J, Zhang G-R, Shi Z-C, Yang R-B, Zou G-W \& Wang W-M 2015 Ghrelin, neuropeptide Y (NPY) and cholecystokinin (CCK) in blunt snout bream (Megalobrama amblycephala): cDNA cloning, tissue distribution and mRNA expression changes responding to fasting and refeeding. General and Comparative Endocrinology 223 108-119. (https://doi.org/10.1016/j. ygcen.2015.08.009)

Johansen SJS, Ekli M \& Jobling M 2002 Is there lipostatic regulation of feed intake in Atlantic salmon Salmo salar L.? Aquaculture Research 33 515-524. (https://doi.org/10.1046/j.1365-2109.2002.00736.x)

Johansen SJS, Sveier H \& Jobling M 2003 Lipostatic regulation of feed intake in Atlantic salmon Salmo salar L. defending adiposity at the 
expense of growth? Aquaculture Research 34 317-331. (https://doi. org/10.1046/j.1365-2109.2003.00820.x)

Jönsson E 2013 The role of ghrelin in energy balance regulation in fish. General and Comparative Endocrinology 187 79-85. (https://doi. org/10.1016/j.ygcen.2013.03.013)

Jönsson E, Kaiya H \& Björnsson BT 2010 Ghrelin decreases food intake in juvenile rainbow trout (Oncorhynchus mykiss) through the central anorexigenic corticotropin-releasing factor system. General and Comparative Endocrinology 166 39-46. (https://doi.org/10.1016/j. ygcen.2009.11.001)

Jørgensen EH, Bernier NJ, Maulec AG \& Vijayanda MM 2016 Effect of long-term fasting and a subsequent meal on mRNA abundances of hypothalamic appetite regulators, central and peripheral leptin expression and plasma leptin levels in rainbow trout. Peptides $\mathbf{8 6}$ 162-170. (https://doi.org/10.1016/j.peptides.2015.08.010)

Klaren PHM, van Dalen SCM, Atsma W, Spanings FAT, Hendriks J \& Flik G 2013 Voluntary timing of food intake increases weight gain and reduces basal cortisol levels in common carp (Cyprinus carpio L.). Physiology and Behavior 122 120-128. (https://doi.org/10.1016/j. physbeh.2013.08.020)

Kohno D 2017 Sweet taste receptor in the hypothalamus: a potential new player in glucose sensing in the hypothalamus. Journal of Physiological Science 67 459-465. (https://doi.org/10.1007/s12576017-0535-y)

Kojima K, Kamijo M, Kageyama H, Uchiyama M, Shioda S \& Matsuda K 2009 Neuronal relationship between orexin-A- and neuropeptide Y-induced orexigenic actions in goldfish. Neuropeptides 43 63-71. (https://doi.org/10.1016/j.npep.2009.01.004)

Kojima K, Amiya N, Kamijo M, Kageyama H, Uchiyama M, Shioda S \& Matsuda K 2010 Relationship between alpha-melanocyte-stimulating hormone- and neuropeptide Y-containing neurons in the goldfish hypothalamus. General and Comparative Endocrinology 167 366-372. (https://doi.org/10.1016/j.ygcen.2009.12.004)

Kruse MS, Suarez LG \& Coirini H 2017 Regulation of the expression of LXR in rat hypothalamic and hippocampal explants. Neuroscience Letters 639 53-58. (https://doi.org/10.1016/j.neulet.2016.12.065)

Kuhar MJ, Adams S, Dominguez G, Jaworski J \& Balkan B 2002 CART peptides. Neuropeptides 36 1-8. (https://doi.org/10.1054/ npep.2002.0887)

Kulczykowska E \& Sánchez-Vázquez FJ 2010 Neurohormonal regulation of feed intake and response to nutrients in fish: aspects of feeding rhythm and stress. Aquaculture Research 41 654-657. (https://doi. org/10.1111/j.1365-2109.2009.02350.x)

Laeger T, Reed SD, Henagan TM, Fernandez DH, Taghavi M, Addington A, Münzberg H, Martin RJ, Hutson SM \& Morrison C 2014 Leucine acts in the brain to suppress food intake but does not function as a physiological signal of low dietary protein. American Journal of Physiology: Regulatory, Integrative and Comparative Physiology 307 R310-R320. (https://doi.org/10.1152/ajpregu.00116.2014)

Lang R, Gundlach AL, Holmes FE, Hobson SA, Wynick D, Hökfelt T \& Kofler B 2015 Physiology, signaling, and pharmacology of galanin peptides and receptors: three decades of emerging diversity. Pharmacology Reviews 67 118-175. (https://doi.org/10.1124/ pr.112.006536)

Lau BK, Cota D, Cristino L \& Borgland SL 2017 Endocannabinoid modulation of homeostatic and non-homeostatic feeding circuits. Neuropharmacology 124 38-51. (https://doi.org/10.1016/j. neuropharm.2017.05.033)

Leal E, Sánchez E, Muriach B \& Cerdá-Reverter JM 2009 Sex steroidinduced food intake inhibition in the sea bass (Dicentrarchus labrax). Journal of Comparative Physiology B 179 77-86. (https://doi. org/10.1007/s00360-008-0285-5)

Leal E, Fernández-Durán B, Guillot R, Ríos D \& Cerdá-Reverter JM 2011 Stress-induced effects on feeding behavior and growth performance of the sea bass (Dicentrarchus labrax): a self-feeding approach. Journal of Comparative Physiology B 181 1035-1044. (https://doi.org/10.1007/ s00360-011-0585-z)

Leal E, Fernández-Durán B, Agulleiro MJ, Conde-Siera M, Míguez JM \& Cerdá-Reverter JM 2013 Effects of dopaminergic system activation on feeding behavior and growth performance of the sea bass (Dicentrarchus labrax): a self-feeding approach. Hormones and Behavior 64 113-121. (https://doi.org/10.1016/j.yhbeh.2013.05.008)

Leibowitz SF \& Rossakis C 1979 L-Dopa feeding suppression: effect on catecholamine neurons of the perifornical lateral hypothalamus. Psychopharmacology 61 273-280. (https://doi.org/10.1007/ BF00432272)

Leknes IL 2015 Mucin in epitelial cells and stomach of black tetra, Gymnocorimbus ternetzi (Characidae, Teleostei). Zoomorphology 134 269-277. (https://doi.org/10.1007/s00435-015-0256-9)

LeSauter J, Hoque N, Weintraub M, Pfaff DW \& Silver R 2009 Stomach ghrelin secreting cells as food-entrainable circadian clocks. PNAS 106 13582-13587. (https://doi.org/10.1073/pnas.0906426106)

Levin BE, Routh VH, Kang L, Sanders NM \& Dunn-Meynell AA 2004 Neuronal glucosensing. What do we know after 50 years? Diabetes 53 2521-2528. (https://doi.org/10.2337/diabetes.53.10.2521)

Li A, Yuan X, Liang XF, Liu L, Li J, Li B, Fang J, Li J, He S, Xue M, et al. 2016 Adaptations of lipid metabolism and food intake in response to low and high fat diets in juvenile grass carp (Ctenopharyngodon idellus). Aquaculture 457 43-49. (https://doi.org/10.1016/j. aquaculture.2016.01.014)

Librán-Pérez M, Polakof S, López-Patiño MA, Míguez JM \& Soengas JL 2012 Evidence of a metabolic fatty-acid sensing system in the hypothalamus and Brockmann bodies of rainbow trout: implications in food intake regulation. American Journal of Physiology: Regulatory, Integrative and Comparative Physiology 302 R1340-R1350. (https://doi. org/10.1152/ajpregu.00070.2012)

Librán-Pérez M, López-Patiño MA, Míguez JM \& Soengas JL 2013 Oleic acid and octanoic acid sensing capacity in rainbow trout Oncorhynchus mykiss is direct in hypothalamus and Brockmann bodies. PLOS ONE $\mathbf{8}$ e59507. (https://doi.org/10.1371/journal.pone.0059507)

Librán-Pérez M, Otero-Rodiño C, López-Patiño MA, Míguez JM \& Soengas JL 2014 Central administration of oleate or octanoate activates hypothalamic fatty acid sensing and inhibits food intake in rainbow trout. Physiology and Behavior 129 272-279. (https://doi. org/10.1016/j.physbeh.2014.02.061)

Librán-Pérez M, Geurden I, Dias K, Corraze G, Panserat S \& Soengas JL 2015 Feeding rainbow trout with a lipid-enriched diet: effects on fatty acid sensing, regulation of food intake and cellular signaling pathways. Journal of Experimental Biology 218 2610-2619. (https:// doi.org/10.1242/jeb.123802)

Liu Y, Zhang Y, Li S, Huang W, Liu X, Lu D, Meng Z \& Lin H 2009 Molecular cloning and functional characterization of the first nonmammalian 26RFa/QRFP orthologue in goldfish, Carassius auratus. Molecular Endocrinology 303 82-90. (https://doi.org/10.1016/j. mce.2009.01.009)

Loh K, Herzog H \& Shi Y-C 2015 Regulation of energy homeostasis by the NPY system. Trends in Endocrinology and Metabolism 26 125-135. (https://doi.org/10.1016/j.tem.2015.01.003)

Londraville RL, Macotel Y, Duff RJ, Easterling MR, Liu Q \& Crespi EJ 2014 Comparative endocrinology of leptin: assessing function in a phylogenetic context. General and Comparative Endocrinology 203 146-157. (https://doi.org/10.1016/j.ygcen.2014.02.002)

López M 2017 Hypothalamic AMPK: a golden target against obesity? European Journal of Endocrinology 176 R235-R246. (https://doi. org/10.1530/EJE-16-0927)

López M, Lelliott CJ \& Vidal-Puig A 2007 Hypothalamic fatty acid metabolism: a housekeeping pathway that regulates food intake. BioEssays 29 248-261.

López-Olmeda JF \& Sánchez-Vázquez FJ 2010 Feeding rhythms in fish: from behavioral to molecular approach. In Biological Clock in Fish, pp 
155-183. Eds E Kulczykowska, W Popek \& BG Kapoor. Enfield: Science Pub CRC Press.

López-Patiño MA, Guijarro AI, Isorna E, Delgado MJ, Alonso-Bedate M \& De Pedro N 1999 Neuropeptide Y has a stimulatory action on feeding behavior in goldfish (Carassius auratus). European Journal of Pharmacology 377 147-153.

Luo L, Xue M, Vachot C, Geurden I \& Kaushik S 2014 Dietary medium chain fatty acids from coconut oild have little effects on postprandial plasma metabolite profiles in rainbow trout (Oncorhynchus mykiss). Aquaculture 420-421 24-31. (https://doi. org/10.1016/j.aquaculture.2013.10.024)

Magnan C, Levin BE \& Luquet S 2015 Brain lipid sensing and the neural control of energy balance. Molecular and Cellular Endocrinology $\mathbf{4 1 8}$ 3-8. (https://doi.org/10.1016/j.mce.2015.09.019)

Marty N, Dallaporta M \& Thorens B 2007 Brain glucose sensing, counteregulation, and energy homeostasis. Physiology 22 241-251. (https://doi.org/10.1152/physiol.00010.2007)

Matsuda K, Miura T, Kaiya H, Maruyama K, Shimakura S-I, Uchiyama M, Kangawa K \& Shioda S 2006 Regulation of food intake by acyl and des-acyl ghrelins in the goldfish. Peptides 27 2321-2325. (https://doi. org/10.1016/j.peptides.2006.03.028)

Matsuda K, Kojima K, Shimakura SI, Miura T, Uchiyama M, Shioda S, Ando H \& Takahashi A 2009a Relationship between melaninconcentrating hormone and neuropeptide Y-containing neurons in the goldfish hypothalamus. Comparative Biochemistry and Physiology A 153 3-7. (https://doi.org/10.1016/j.cbpa.2008.10.002)

Matsuda K, Kojima K, Shimakura SI \&Takahashi A 2009b Regulation of food intake by melanin-concentrating hormone in goldfish. Peptides 30 2060-2065. (https://doi.org/10.1016/j.peptides.2009.02.015)

Matsuda K, Sakashita A, Yokobori E \& Azuma M 2012 Neuroendocrine control of feeding behavior and psychomotor activity by neuropeptide Y in fish. Neuropeptides 46 275-283. (https://doi. $\operatorname{org} / 10.1016 /$ j.npep.2012.09.006)

Maurin AC, Benani A, Lorsignol A, Brenachot X, Parry L, Carraro V, Guissard C, Averous J, Jousse C, Bruhat A, et al. 2014 Hypothalamic elF2 $\alpha$ signaling regulates food intake. Cell Reports 6 438-444. (https://doi.org/10.1016/j.celrep.2014.01.006)

Mendoza J \& Challet E 2009 Brain clocks: from the suprachiasmatic nuclei to a cerebral network. Neuroscientist 15 477-488. (https://doi. org/10.1177/1073858408327808)

Mendoza J, Pevet P, Felder-Schmittbuhl MP, Bailly Y \& Challet E 2010 The cerebellum harbors a circadian oscillator involved in food anticipation. Journal of Neuroscience 30 1894-1904. (https://doi. org/10.1523/JNEUROSCI.5855-09.2010)

Mensah ET, Volkoff H \& Unniappan S 2010 Galanin systems in nonmammalian vertebrates with special focus on fishes. In Galanin, pp 243-262. Ed T Hökfelt. Basel: Springer.

Mercer RE, Chee MJ \& Colmers WF 2011 The role of NPY in hypothalamic mediated food intake. Frontiers in Neuroendocrinology 32 398-415. (https://doi.org/10.1016/j.yfrne.2011.06.001)

Meredith GE \& Smeets WJ 1987 Immunocytochemical analysis of the dopamine system in the forebrain and midbrain of Raja radiata: evidence for a substantia nigra and ventral tegmental area in cartilaginous fish. Journal of Comparative Neurology 265 530-548. (https://doi.org/10.1002/cne.902650407)

Meyer A \& Van de Peer Y 2005 From 2R to 3R: evidence for a fishspecific genome duplication (FSGD). BioEssays 27 937-945. (https:// doi.org/10.1002/bies.20293)

Michel M, Page-McCaw PS, Chen W \& Cone RD 2016 Leptin signaling regulates glucose homeostasis, but not adipostasis, in the zebrafish. PNAS 113 3084-3089. (https://doi.org/10.1073/ pnas.1513212113)

Mistlberger RE 2011 Neurobiology of food anticipatory circadian rhythm. Physiology and Behavior 104 535-545. (https://doi. org/10.1016/j.physbeh.2011.04.015)
Mitro N, Mak PA, Vargas L, Godio C, Hampton E, Molteni V, Kreusch A \& Saez E 2007 The nuclear receptor LXR is a glucose sensor. Nature 445 219-223. (https://doi.org/10.1038/nature05449)

Miura T, Maruyama K, Shimakura S, Kaiya H, Uchiyama M, Kangawa K, Shioda S \& Matsuda K 2006 Neuropeptide Y mediates ghrelininduced feeding in the goldish, Carassius auratus. Neuroscience Letters 407 279-283. (https://doi.org/10.1016/j.neulet.2006.08.071)

Miura TK, Maruyama SI, Shimakura H, Kaiya M, Uchiyama K, Kangawa S, Shioda K \& Matsuda K 2007 Regulation of food intake in the goldfish by interaction between ghrelin and orexin Peptides $\mathbf{2 8}$ 1207-1213. (https://doi.org/10.1016/j.peptides.2007.03.023)

Mobbs CV, Isoda F, Makimura H, Mastaitis J, Mizuno T, Shu I-W, Yen K \& Yang X-J 2005 Impaired glucose signaling as a cause of obesity and the metabolic syndrome: the glucoadipostatic hypothesis. Physiology and Behavior 85 2-23. (https://doi.org/10.1016/j.physbeh.2005.04.005)

Mojsov S 2000 Glucagon-like peptide1 (glp-1) and the control of glucose metabolism in mammals and teleost fish. American Zoology $\mathbf{4 0}$ 246-258. (https://doi.org/10.1668/0003-1569(2000)040[0246:GLPGA $\mathrm{T}] 2.0 . \mathrm{CO} ; 2)$

Mommsen TP \& Moon TW 1989 Metabolic actions of glucagon-family hormones in liver. Fish Physiology and Biochemistry 7 279-288. (https://doi.org/10.1007/BF00004718)

Moore HA \& Whitmore D 2014 Circadian rhythmicity and light sensitivity of the zebrafish brain. PLOS ONE 9 e86176. (https://doi. org/10.1371/journal.pone.0086176)

Morais S 2017 The physiology of taste in fish: potential implications for feeding stimulation and gut chemical sensing. Reviews in Fisheries Science and Aquaculture 25 133-149. (https://doi.org/10.1080/233082 49.2016.1249279)

Moran TH \& Kinzig KP 2004 Gastrointestinal satiety signals II. Cholecystokinin. American Journal of Physiology: Gastrointestinal and Liver Physiology 286 G183-G188. (https://doi.org/10.1152/ajpgi.00434.2003)

Morris DL \& Rui L 2009 Recent advances in understanding leptin signaling and leptin resistance. American Journal of Physiology: Endocrinology and Metabolism 297 E1247-E1259. (https://doi. org/10.1152/ajpendo.00274.2009)

Morrison CD 2005 Leptin inhibits hypothalamic Npy and Agrp gene expression via a mechanism that requires phosphatidylinositol 3-OH-kinase signaling. American Journal of Physiology: Endocrinology and Metabolism 289 E1051-E1057. (https://doi.org/10.1152/ ajpendo.00094.2005)

Morrison CD \& Laeger T 2015 Protein-dependent regulation of feeding and metabolism. Trends in Endocrinology and Metabolism 26 256-262. (https://doi.org/10.1016/j.tem.2015.02.008)

Morrison CD, Xi X, White CL, Ye J \& Martin RJ 2016 Amino acids inhibit Agrp gene expression via an mTOR-dependent mechanism. American Journal of Physiology: Endocrinology and Metabolism 293 E165-E171. (https://doi.org/10.1152/ajpendo.00675.2006)

Morton GJ, Cummings DE, Baskin DG, Barsh GS \& Schwartz MW 2006 Central nervous system control of food intake and body weight. Nature 443 289-295. (https://doi.org/10.1038/nature05026)

Morton GJ, Meek TH \& Schwartz MW 2014 Neurobiology of food intake in health and disease. Nature Reviews Neuroscience 15 367-378. (https://doi.org/10.1038/nrn3745)

Mourente G \& Tocher DR 1992 Lipid class and fatty acid composition of brain lipids from Atlantic herring (Clupea harengus) at different stages of development. Marine Biology 112 553-558. (https://doi. org/10.1007/BF00346172)

Mueller T 2011 The conserved plan of the teleostean telencephalon. Brain Behavior and Evolution 78 259-260. (https://doi. org/10.1159/000331869)

Mueller T 2012 What is the thalamus in zebrafish? Frontiers in Neuroscience 6 64. (https://doi.org/ 10.3389/fnins.2012.00064)

Mueller T \& Guo S 2009 The distribution of GAD67-mRNA in the adult zebrafish (teleost) forebrain reveals a prosomeric pattern and suggests 
previously unidentified homologies to tetrapods. Journal of Comparative Neurology 516 553-568. (https://doi.org/10.1002/ cne.22122)

Mueller T \& Wullimann MF 2009 An evolutionary interpretation of teleostean forebrain anatomy. Brain Behavior and Evolution 74 30-42. (https://doi.org/10.1159/000229011)

Müller TD, Nogueiras R, Andermann ML, Andrews ZB, Anker SD, Argente J, Batterham RL, Benoit SC, Bowers CY, Broglio F, et al. 2015 Ghrelin. Molecular Metabolism 4 437-460.

Nagai K, Nishio T, Nakagawa H, Nakamura S \& Fukuda Y 1978 Effect of bilateral lesions of the suprachiasmatic nuclei on the circadian rhythm of food-intake. Brain Research 142 384-389. (https://doi. org/10.1016/0006-8993(78)90648-0)

Nahon JL 2006 The melanocortins and melanin-concentrating hormone in the central regulation of feeding behavior and energy homeostasis. Comptes Rendus Biologies 329 623-638. (https://doi. org/10.1016/j.crvi.2006.03.021)

Narnaware Y \& Peter RE 2002 Influence of diet composition on food intake and neuropeptide Y (NPY) gene expression in goldfish brain. Regulatory Peptides 103 75-83. (https://doi.org/10.1016/S01670115(01)00342-1)

Navarro I \& Gutiérrez J 1995 Fasting and starvation. In Metabolic Biochemistry, Biochemistry and Molecular Biology of Fishes, vol 4, pp 393-434. Eds PW Hochachka \& TP Mommsen. Amsterdam: Elsevier.

Near TJ, Eytan RI, Dornburg A, Kuhn KL, Moore JA, Davis MP, Wainwright PC, Friedman M \& Smith WL 2012 Resolution of rayfinned fish phylogeny and timing of diversification. PNAS 109 13698-13703. (https://doi.org/10.1073/pnas.1206625109)

Nelson JS 2006 Fishes of the World. New Jersey: John Wiley and Sons.

Nelson LE \& Sheridan MA 2006 Gastroenteropancreatic hormones and metabolism in fish. General and Comparative Endocrinology 148 116-124. (https://doi.org/10.1016/j.ygcen.2006.01.011)

Nieuwenhuys R 1959 The structure of the telencephalon of the teleost Gasterosteus aculeatus I and II. Proceedings van de Koninklijke Nederlandse Akademie van Wetenschappen Section C 62 341-362.

Nisembaum LG, Velarde E, Tinoco AB, Azpeleta C, de Pedro N, AlonsoGómez AL, Delgado MJ \& Isorna E 2012 Light-dark cycle and feeding time differentially entrains the gut molecular clock of the goldfish (Carassius auratus). Chronobiology International 29 665-673. (https:// doi.org/10.3109/07420528.2012.686947)

Nisembaum LG, De Pedro N, Delgado MJ \& Isorna E 2014 Crosstalking between the 'gut-brain' hormone ghrelin and the circadian system in the goldfish. Effects on clock gene expression and food anticipatory activity. General and Comparative Endocrinology 205 287-295 (https://doi.org/10.1016/j.ygcen.2014.03.016)

Nogueiras R, Romero-Picó A, Vazquez MJ, Novelle MG, López M \& Diéguez C 2012 The opioid system and food intake: homeostatic and hedonic mechanisms. Obesity Facts 5 196-207. (https://doi. org/10.1159/000338163)

Norhcutt RG 1995 The forebrain of gnathostomes: in search of a morphotype. Brain Behavior and Evolution 46 275-318. (https://doi. org/10.1159/000113279)

Northcutt RG \& Davis RE 1983 Telencephalic organization in ray-finned fishes. In Fish Neurobiology, vol. 2, pp 203-236. Eds RE Davis \& RG Northcutt. Ann Arbor: University of Michigan Press.

Ogunnowo-Bada E, Heeley N, Brochard L \& Evans ML 2014 Brain glucose sensing, glucokinase and nural control of metabolism and islet function. Diabetes, Obesity and Metabolism 16 (Supplement 1) 26-32. (https://doi.org/10.1111/dom.12334)

Olsson C 2011 Gut anatomy and morphology. In Encyclopedia of Fish Physiology from Genome to Environment. Eds AP Farrell, ED Stevens, JJ Cech Jr \& JG Richards. New York: Academic Press.

Ooyama Y, Kojima K, Aoyama T \& Takeuchi H 2009 Decrease of food intake in rats after ingestion of medium-chain triacylglycerol. Journal of Nutritional Science and Vitaminology 55 423-427. (https://doi. org/10.3177/jnsv.55.423)
Otero-Rodiño C, Librán-Pérez M, Velasco C, López-Patiño MA, Míguez JM \& Soengas JL $2015 a$ Evidence for the presence of glucosensor mechanisms not dependent on glucokinase in hypothalamus and hindbrain of rainbow trout (Oncorhynchus mykiss). PLoS ONE 10 e0128603. (https://doi.org/10.1371/journal. pone.0128603)

Otero-Rodiño C, Librán-Pérez M, Velasco C, Álvarez-Otero R, LópezPatiño MA, Míguez JM \& Soengas JL 2015b Response of lactate metabolism in brain glucosensing areas of rainbow trout (Oncorhynchus mykiss) to changes in glucose levels. Journal of Comparative Physiology B 185 869-882. (https://doi.org/10.1007/ s00360-015-0932-6)

Otero-Rodiño C, Velasco C, Álvarez-Otero R, López-Patiño MA, Míguez JM \& Soengas JL 2016 In vitro evidence in rainbow trout supporting glucosensing mediated by sweet taste receptor, LXR, and mitochondrial activity in Brockmann bodies, and sweet taste receptor in liver. Comparative Biochemistry and Physiology B 200 6-16. (https://doi.org/10.1016/j.cbpb.2016.04.010)

Otero-Rodiño C, Velasco C, Álvarez-Otero R, López-Patiño MA, Míguez JM \& Soengas JL 2017 Changes in the levels and phosphorylation status of Akt, AMPK, CREB, and FoxO1 in hypothalamus of rainbow trout under conditions of enhanced glucosensing activity. Journal of Experimental Biology 220 4410-4417. (https://doi.org/10.1242/jeb.165159)

Palmiter RD 2007 Is dopamine a physiologically relevant mediator of feeding behavior? Trends in Neuroscience 30 375-381. (https://doi. org/10.1016/j.tins.2007.06.004)

Paspatis M, Boujard T, Maragoudaki D, Blanchard G \& Kentouri M 2003 Do stocking density and feed reward level affect growth and feeding of self-fed juvenile European sea bass? Aquaculture 216 103-113. (https://doi.org/10.1016/S0044-8486(02)00417-9)

Pasquier J, Cabau C, Nguyen T, Jouanno E, Severac D, Braasch I, Journot L, Pontarotti P, Klopp C, Postlethwait JH, Guiguen Y \& Bobe J 2016 Gene evolution and gene expression after whole genome duplication in fish: the PhyloFish database. BMC Genomics 17 368. (https://doi.org/10.1186/s12864-016-2709-z)

Pellerin L \& Magistretti PJ 2012 Sweet sixteen for ANLS. Journal of Cerebral Blood Flow and Metabolism 32 1152-1166. (https://doi. org/10.1038/jcbfm.2011.149)

Peyon P, Saied H, Lin X \& Peter RE 1999 Postprandial, seasonal and sexual variations in cholecystokinin gene expression in goldfish brain. Molecular Brain Research 74 190-196. (https://doi.org/10.1016/ S0169-328X(99)00282-X)

Piccinetti CC, Migliarini B, Petrosino S, Di Marzo V \& Carnevali O 2010 Anandamide and AM251, via water, modulate food intake at central and peripheral level in fish. General and Comparative Endocrinology 166 259-267. (https://doi.org/10.1016/j.ygcen.2009.09.017)

Pitts PM \& Volkoff H 2017 Characterization of appetite-regulating factors in platyfish, Xiphophorus maculatus (Cyprinodontiformes Poeciliidae). Comparative Biochemistry and Physiology - Part A : Molecular and Integrative Physiology 208 80-88. (https://doi.org/ 10.1016/j.cbpa.2017.03.018)

Polakof S \& Soengas JL 2008 Involvement of lactate in glucose metabolism and glucosensing function in selected tissues of rainbow trout. Journal of Experimental Biology 211 1075-1086. (https://doi. org/10.1242/jeb.014050)

Polakof S, Míguez JM, Moon TW \& Soengas JL 2007 Evidence for the presence of a glucosensor in hypothalamus, hindbrain, and Brockmann bodies of rainbow trout. American Journal of Physiology: Regulatory, Integrative and Comparative Physiology 292 R1657-R1666. (https://doi.org/10.1152/ajpregu.00525.2006)

Polakof S, Míguez JM \& Soengas JL 2008a Changes in food intake and glucosensing function of hypothalamus and hindbrain in rainbow trout subjected to hyperglycemic or hypoglycemic conditions. Journal of Comparative Physiology A 194 829-839. (https://doi. org/10.1007/s00359-008-0354-y) 
Polakof S, Míguez JM \& Soengas JL 2008b Dietary carbohydrates induce changes in glucosensing capacity and food intake in rainbow trout. American Journal of Physiology: Regulatory, Integrative and Comparative Physiology 295 R478-R489. (https://doi.org/10.1152/ ajpregu.00176.2008)

Polakof S, Panserat S, Plagnes-Juan E \& Soengas JL 2008c Altered dietary carbohydrates significantly affect gene expression of the major glucosensing components in Brockmannn bodies and hypothalamus of rainbow trout. American Journal of Physiology: Regulatory, Integrative and Comparative Physiology 295 R1077-R1088. (https://doi. org/10.1152/ajpregu.90476.2008)

Polakof S, Rodríguez-Alonso M \& Soengas JL 2009 Immunohistochemical localization of glucokinase in rainbow trout brain. Comparative Biochemistry and Physiology A 153 352-358. (https://doi.org/10.1016/j.cbpa.2009.03.015)

Polakof S, Médale F, Skiba-Cassy S, Corraze G \& Panserat S 2010 Molecular regulation of lipid metabolism in liver and muscle of rainbow trout subjected to acute and chronic insulin treatments. Domestic Animal Endocrinology 39 26-33. (https://doi.org/10.1016/j. domaniend.2010.01.003)

Polakof S, Míguez JM \& Soengas JL 2011a Evidence for a gut-brain axis used by glucagon-like peptide- 1 to elicit hyperglycaemia in fish. Journal of Neuroendocrinology 23 508-518. (https://doi. $\operatorname{org} / 10.1111 / \mathrm{j} .1365-2826.2011 .02137 . x)$

Polakof S, Mommsen TP \& Soengas JL $2011 b$ Glucosensing and glucose homeostasis: from fish to mammals. Comparative Biochemistry and Physiology B 160 123-149. (https://doi.org/10.1016/j. cbpb.2011.07.006)

Polakof S, Panserat S, Soengas JL \& Moon TW 2012 Glucose metabolism in fish: a review. Journal of Comparative Physiology B 182 1015-1045. (https://doi.org/10.1007/s00360-012-0658-7)

Portavella M, Torres B \& Salas C 2004 Avoidance response in goldfish: emotional and temporal involvement of medial and lateral telencephalic pallium. Journal of Neuroscience 24 2335-2342. (https:// doi.org/10.1523/JNEUROSCI.4930-03.2004)

Reddy AB, Maywood ES, Karp NA, King VM, Inoue Y, Gonzalez FJ, Lilley KS, Kyriacou CP \& Hastings MH 2007 Glucocorticoid signalling synchronizes the liver circadian transcriptome. Hepatology 45 1478-1488. (https://doi.org/10.1002/hep.21571)

Rehfeld JF 2004 A centenary of gastrointestinal endocrinology. Hormone and Metabolic Research 36 735-741. (https://doi. org/10.1055/s-2004-826154)

Riley LG, Fox BK, Kaiya H, Hirano T \& Grau EG 2005 Long-term treatment of ghrelin stimulates feeding, fat deposition, and alters the GH/IGF-I axis in the tilapia, Oreochromis mossambicus. General and Comparative Endocrinology 142 234-240. (https://doi.org/10.1016/j. ygcen.2005.01.009)

Rink E \& Wulliman MF 1998 Some forebrain connection of the gustatory system in the goldfish Carassius auratus visualized by separate DiI application to the hypothalamic inferior lobe and the torus lateralis. Journal of Comparative Neurology 394 152-170. (https:// doi.org/10.1002/(SICI)1096-9861(19980504)394:2<152::AIDCNE2>3.0.CO;2-1)

Rink E \& Wullimann MF 2001 The teleostean (zebrafish) dopaminergic system ascending to the subpallium (striatum) is located in the basal diencephalon (posterior tuberculum). Brain Research 889 316-330. (https://doi.org/10.1016/S0006-8993(00)03174-7)

Rink E \& Wullimann MF 2002 Connections of the ventral telencephalon and tyrosine hydroxylase distribution in the zebrafish brain (Danio rerio) lead to identification of an ascending dopaminergic system in a teleost. Brain Research Bulletin 57 385-387. (https://doi. org/10.1016/S0361-9230(01)00696-7)

Rodríguez F, López JC, Vargas JP, Gómez Y, Broglio C \& Salas C 2002 Conservation of spatial memory function in the pallial forebrain of amniotes and ray-finned fishes. Journal of Neuroscience 22 2894-2903.
Rogers PJ \& Brunstrom JM 2016 Appetite and energy balancing. Physiology and Behavior 164 465-471. (https://doi.org/10.1016/j. physbeh.2016.03.038)

Rogers RC, Ritter S \& Hermann GE 2016 Hindbrain cytoglucopeniainduced increases in systemic blood glucose levels by 2-deoxyglucose depend on intact astrocytes and adenosine release. American Journal of Physiology: Regulatory, Integrative and Comparative Physiology $\mathbf{3 1 0}$ R1102-R1108. (https://doi.org/10.1152/ajpregu.00493.2015)

RØnnestad I, Gomes AS, Murashita K, Angotzi R, Jönsson E \& Volkoff H 2017 Appetite-controlling endocrine systems in teleosts. Frontiers in Endocrinology 8 73. (https://doi.org/10.3389/fendo.2017.00073)

Rossi MA \& Stuber GD 2017 Overlapping brain circuits for homeostatic and hedonic feeding. Cell Metabolism 27 42-56. (https://doi. org/10.1016/j.cmet.2017.09.021)

Rubio VC, Sánchez-Vázquez FJ, Zamora S \& Madrid JA 2008 Endogenous modification of macronutrient selection pattern in sea bass (Dicentrarchus labrax, L.). Physiology and Behavior 95 32-35. (https:// doi.org/10.1016/j.physbeh.2008.03.006)

Rui L 2013 Brain regulation of energy balance and body weights. Reviews in Endocrine and Metabolic Disorders 14 387-407. (https://doi. org/10.1007/s11154-013-9261-9)

Ruibal C, Soengas JL \& Aldegunde M 2002 Brain serotonin and the control of food intake in rainbow trout (Oncorhynchus mykiss): effects of changes in plasma glucose levels. Journal of Comparative Physiology A 188 479-484. (https://doi.org/10.1007/s00359-002-0320-z)

Sakurai T 2006 Roles of orexins and orexin receptors in central regulation of feeding behavior and energy homeostasis. CNS AND Neurological Disorders-Drug Targets 5 313-325. (https://doi. org/10.2174/187152706777452218)

Salas C, Broglio C, Durán E, Gómez A, Ocaña FM, Jiménez-Moya F \& Rodríguez F 2006 Neuropsychology of learning and memory in teleost fish. Zebrafish 3 157-171. (https://doi.org/10.1089/ zeb.2006.3.157)

Sam AH, Troke RC, Tan TM \& Bewick GA 2012 The role of the gut/brain axis in modulating food intake. Neuropharmacology 63 46-56. (https://doi.org/10.1016/j.neuropharm.2011.10.008)

Sánchez E, Rubio VC, Thompson D, Metz J, Flik G, Millhauser GL \& Cerdá-Reverter JM 2009 Phosphodiesterase inhibitor-dependent inverse agonism of agouti-related protein (AGRP) on melanocortin 4 receptor in sea bass (Dicentrarchus labrax). American Journal of Physiology: Regulatory, Integrative and Comparative Physiology 296 R1293-R1306. (https://doi.org/10.1152/ajpregu.90948.2008)

Sánchez-Bretaño A, Alonso-Gómez AL, Delgado MJ \& Isorna E 2015 The liver of goldfish as a component of the circadian system: integrating a network of signals. General and Comparative Endocrinology 221 213-216. (https://doi.org/10.1016/j.ygcen.2015.05.001)

Sánchez-Bretaño A, Callejo M, Montero M, Alonso-Gómez AL, Delgado MJ \& Isorna E 2016 PER forming a hepatic timing signal: glucocorticoids induce gper $1 a$ and gper $1 b$ expression and repress gclock $1 a$ and gbmal1a in the liver of goldfish. Journal of Comparative Physiology B 186 73-82.

Sánchez-Bretaño A, Blanco AM, Alonso-Gómez AL, Delgado MJ, Kah O \& Isorna E 2017 Ghrelin induces clock gene expression in the liver of goldfish in vitro via protein kinase $\mathrm{C}$ and protein kinase $\mathrm{A}$ pathways. Journal of Experimental Biology 220 1295-1306. (https:// doi.org/10.1242/jeb.144253)

Sánchez-Muros MJ, García-Rejón L, García-Salguero L, de la Higuera M \& Lupiáñez JA 1998 Long-term nutritional effects on the pimary liver and kidney metabolism in rainbow trout. Adaptative response to starvation and high-protein, carbohydrate-free diet to glutamate dehydrogenase and alanine aminotransferase kinetics. International Journal of Biochemistry 30 55-63.

Sandoval DA \& D'Alessio DA 2015 Physiology of proglucagon peptides: role of glucagon and GLP-1 in health and disease. Physiological Reviews 95 513-548. (https://doi.org/10.1152/physrev.00013.2014) 
Saravanan S, Geurden I, Figueiredo-Silva AC, Kaushik S, Haidar MN, Verreth JAJ \& Schrama JW 2012 Control of voluntary feed intake in fish: a role for dietary oxygen demand in Nile tilapia (Oreochromis niloticus) fed diets with different macronutrient profiles. British Journal of Nutrition 108 1519-1529. (https://doi.org/10.1017/ S0007114511006842)

Saravanan S, Geurden I, Figueiredo-Silva AC, Kaushik S, Verreth JAJ \& Schrama JW 2013 Voluntary feed intake in rainbow trout is regulated by diet-induced diferences in oxygen use. Journal of Nutrition 143 781-787. (https://doi.org/10.3945/jn.112.173062)

Sargent JR, Tocher DR \& Bell JG 2002 The lipids. In Fish Nutrition, pp 182-258. Eds JE Halver \& RW Hardy. San Diego: Academic Press.

Schibler U, Gotic I, Saini C, Gos P, Curie T, Emmenegger Y, Sinturel F, Gosselin P, Gerber A, Fleury-Olela F, et al. 2015 Clock-talk: interactions between central and peripheral circadian oscillators in mammals. Cold Spring Harbor Symposia on Quantitative Biology 80 223-232. (https://doi.org/10.1101/sqb.2015.80.027490)

Schneeberger M, Gomis R \& Claret M 2014 Hypothalamic and brainstem neuronal circuits controlling homeostatic energy balance. Journal of Endocrinology 220 T25-T46. (https://doi.org/10.1530/JOE13-0398)

Schneeman B 2004 Food factors and gastrointestinal function: a critical interface. Biofactors 21 85-88. (https://doi.org/10.1002/ biof.552210116)

Schwartz MW, Woods SC, Porte D Jr, Seeley RJ \& Baskin DG 2000 Central nervous system control of food intake. Nature $\mathbf{4 0 4} 661-671$. (https://doi.org/10.1038/35007534)

Schwinkendorf DR, Tsatsos NG, Gosnell BA \& Mashek DG 2011 Effects of central administration of distinct fatty acids on hypothalamic neuropeptide expression and energy metabolism. International Journal of Obesity 35 336-344. (https://doi.org/10.1038/ijo.2010.159)

Shearer KD, Silverstein J \& Plisetskaya EM 1997 Role of adiposity in food intake control of juvenile chinook salmon (Oncorhynchus tshawytscha). Comparative Biochemistry and Physiology A 118 1209-1215. (https://doi.org/10.1016/S0300-9629(97)86801-6)

Sheridan MA 1994 Regulation of lipid metabolism in poikilothermic vertebrates. Comparative Biochemistry and Physiology B 107 495-508. (https://doi.org/10.1016/0305-0491(94)90176-7)

Silverstein JT, Shearer KD, Dickhoff WW \& Plisetskaya EM 1999 Regulation of nutrient intake and energy balance in salmon. Aquaculture 177 161-169. (https://doi.org/10.1016/S00448486(99)00076-9)

Skiba-Cassy S, Panserat S, Larquier M, Dias K, Surget A, Plagnes-Juan E, Kaushik S \& Seiliez I 2013 Apparent low ability of liver and muscle to adapt to variation of dietary carbohydrate:protein ratio in rainbow trout (Oncorhynchus mykiss). British Journal of Nutrition 109 1359-1372. (https://doi.org/10.1017/S0007114512003352)

Soares MC, Cardoso SC, Malato JT \& Messias JPM 2017 Can cleanerfish overcome temptation? A selective role for dopamine influence on cooperative-based decision making. Physiology and Behavior 169 124-129. (https://doi.org/10.1016/j.physbeh.2016.11.028)

Soengas JL 2014 Contribution of glucose- and fatty acid sensing systems to the regulation of food intake in fish. A review. General and Comparative Endocrinology 205 36-48. (https://doi.org/10.1016/j. ygcen.2014.01.015)

Soengas JL \& Aldegunde M 2002 Energy metabolism of fish brain. Comparative Biochemistry and Physiology B 131 271-296. (https://doi. org/10.1016/S1096-4959(02)00022-2)

Sohn JW 2015 Network of hypothalamic neurons that control appetite. BMB Reports 48 229-233. (https://doi.org/10.5483/ BMBRep.2015.48.4.272)

Spiga F, Walker JJ, Terry JR \& Lightman SL 2014 HPA axis-rhythms. Comprehensive Physiology 4 1273-1298.

Steinbusch L, Labouèbe G \& Thorens B 2015 Brain glucose sensing in homeostatic and hedonic regulation. Trends in Endocrinology and
Metabolism 26 455-466. (https://doi.org/10.1016/j. tem.2015.06.005)

Steensels S \& Depoortere I 2018 Chemoreceptors in the gut. Annual Review of Physiology 80 5.1-5.25 (https://doi.org/10.1146/annurevphysiol-021317-121332)

Stephan FK 2002 The 'other' circadian system: food as a zeitgeber. Journal of Biological Rhythms 17 284-292. (https://doi. org/10.1177/074873002129002591)

Stokkan K-A, Yamazaki S, Tei H, Sakaki Y \& Menaker M 2001. Entrainment of the circadian clock in the liver by feeding. Science 291 490-493. (https://doi.org/10.1126/science.291.5503.490)

Suárez MD, Sanz A, Bazoco J \& García-Gallego M 2002 Metabolic effects of changes in the dietary protein:carbohydrate ratio in eel (Anguilla anguilla) and trout (Oncorhynchus mykiss). Aquaculture International 10 143-156.

Szczypka MS, Rainey MA, Kim DS, Alaynick WA, Marck BT, Matsumoto AM \& Palmiter RD 1999 Feeding behavior in dopaminedeficient mice. PNAS 96 12138-12143. (https://doi.org/10.1073/ pnas.96.21.12138)

Szczypka MS, Kwok K, Brot MD, Marck BT, Matsumoto AM, Donahue BA \& Palmiter RD 2001 Dopamine production in the caudate putamen restores feeding in dopamine-deficient mice. Neuron 30 819-828. (https://doi.org/10.1016/S0896-6273(01)00319-1)

Takahashi A, Davis P, Reinick C, Mizusawa K, Sakamoto T \& Dores RM 2016 Characterization of melanocortin receptors from stingray Dasyatis akajei, a cartilaginous fish. General and Comparative Endocrinology 232 115-124. (https://doi.org/10.1016/j. ygcen.2016.03.030)

Takeuchi S 2016 Agouti-related protein A2. In Handbook of Hormones, pp 70-71. Eds H Ando \& K Tsutsui. San Diego: Academic Press.

Thorens B 2012 Sensing of glucose in the brain. In Appetite Control, pp 277-293. Ed H-G Joost. Berlin: Springer-Verlag.

Tine M, Kuhl H, Teske PR, Tschöp MH \& Jastroch M 2016 Diversification and coevolution of the ghrelin/growth hormone secretagogue receptor system in vertebrates. Ecology and Evolution 6 2516-2535. (https://doi.org/10.1002/ece3.2057)

Tinoco AB, Nisembaum LG, Isorna E, Delgado MJ \& De Pedro N 2012 Leptins and leptin receptor expression in the goldfish (Carassius auratus). Regulation by food intake and fasting/overfeeding conditions Peptides 34 329-335. (https://doi.org/10.1016/j. peptides.2012.02.001)

Tinoco AB, Näslund J, Delgado MJ, De Pedro N, Johnsson JI \& Jönsson E $2014 a$ Ghrelin increases food intake, swimming activity and growth in juvenile brown trout (Salmo trutta). Physiology and Behavior 124 15- 22. (https://doi.org/10.1016/j.physbeh.2013.10.034)

Tinoco AB, Armirotti A, Isorna E, Delgado MJ, Piomelli D \& De Pedro N $2014 b$ Role of oleoylethanolamide as a feeding regulator in goldfish. Journal of Experimental Biology 217 2761-2769. (https://doi. org/10.1242/jeb.106161)

Tinoco AB, Valenciano AI, Gómez-Boronat M, Blanco AM, Nisembaum LG, De Pedro N \& Delgado MJ 2015 Two cholecystokinin receptor subtypes are identified in goldfish, being the CCKAR involved in the regulation of intestinal motility. Comparative Biochemistry and Physiology A 187 193-201. (https://doi. org/10.1016/j.cbpa.2015.05.027)

Tocher DR 2003 Metabolism and functions of lipids and fatty acids in teleost fish. Reviews in Fisheries Science 11 107-184. (https://doi. org/10.1080/713610925)

Tritos NA \& Maratos-Flier E 1999 Two important systems in energy homeostasis: melanocortins and melanin-concentrating hormone. Neuropeptides 33 339-349. (https://doi.org/10.1054/npep.1999.0055)

Trushenski JT 2009 Saturated lipid sources in feeds for sunshine bass: alterations in production performance and tissue fatty acid composition. North American Journal of Aquaculture 71 363-373. (https://doi.org/10.1577/A09-001.1) 
Turek FW, Joshu C, Kohsaka A, Lin E, Ivanova G, McDearmon E, Laposky A, Losee-Olson S, Easton A, Jensen DR, et al. 2005 Obesity and metabolic syndrome in circadian clock mutant mice. Science 308 1043-1045. (https://doi.org/10.1126/ science.1108750)

Tyree SM \& de Lecea L 2017 Lateral hypothalamic control of the ventral tegmental area: reward evaluation and the driving of motivated behavior. Frontiers in Systematic Neuroscience 11 1-9.

Unniappan S \& Peter RE 2005 Structure, distribution and physiological functions of ghrelin in fish. Comparative Biochemistry and Physiology A 140 396-408. (https://doi.org/10.1016/j.cbpb.2005.02.011)

Valenti M, Cottone E, Martínez R, De Pedro N, Viveros MP, Franzoni F, Delgado MJ \& Di Marzo V 2005 The endocannabinoid system in the brain of Carassius auratus and its posible role in the control of food intake. Journal of Neurochemistry 95 662-672. (https://doi. org/10.1111/j.1471-4159.2005.03406.x)

van de Pol I, Flik G \& Gorissen M 2017 Comparative physiology of energy metabolism: fishing for endocrine signals in the early vertebrate pool. Frontiers in Endocrinology 836 . (https://doi. org/10.3389/fendo.2017.00036)

Vastermark A \& Schiöth HB 2011 The early origin of melanocortin receptors, agouti-related peptide, agouti signaling peptide, and melanocortin receptor accessory proteins, with emphasis on pufferfishes, elephant shark, lampreys, and amphioxus. European Journal of Pharmacology 660 61-69. (https://doi.org/10.1016/j. ejphar.2010.10.106)

Velasco C, Librán-Pérez M, Otero-Rodiño C, López-Patiño MA, Míguez JM, Cerdá-Reverter JM \& Soengas JL 2016a Ghrelin modulates hypothalamic fatty acid-sensing and control of food intake in rainbow trout. Journal of Endocrinology 228 25-37. (https:// doi.org/10.1530/JOE-15-0391)

Velasco C, Librán-Pérez M, Otero-Rodiño C, López-Patiño MA, Míguez JM \& Soengas JL 2016b Ceramides are involved in the regulation of food intake in rainbow trout (Oncorhynchus mykiss). American Journal of Physiology: Regulatory, Integrative and Comparative Physiology 311 R658-R668. (https://doi.org/10.1152/ ajpregu.00201.2016)

Velasco C, Otero-Rodiño C, Comesaña, S, Míguez JM \& Soengas JL 2017 Hypothalamic mechanisms linking fatty acid sensing and food intake regulation in rainbow trout. Journal of Molecular Endocrinology 59 377-390. (https://doi.org/10.1530/JME-17-0148)

Vera LM, De Pedro N, Gomez-Milán E, Delgado MJ, Sánchez-Muros MJ, Madrid JA \& Sánchez-Vázquez FJ 2007 Feeding entrainment of locomotor activity rhythms, digestive enzymes and neuroendocrine factors in goldfish. Physiology and Behaviour 90 518-524. (https://doi. org/10.1016/j.physbeh.2006.10.017)

Volff JN 2004 Genome evolution and biodiversity in teleost fish. Heredity 94 280-294. (https://doi.org/10.1038/sj.hdy.6800635)

Volkoff H 2016 The neuroendocrine regulation of food intake in fish: a review of current knowledge. Frontiers in Neuroscience 10540.

Volkoff H \& Peter RE 2001 Interactions between orexin A, NPY and galanin in the control of food intake of the goldfish, Carassius auratus. Regulatory Peptides 101 59-72. (https://doi.org/10.1016/ S0167-0115(01)00261-0)

Volkoff H, Bjorklund JM \& Peter RE 1999 Stimulation of feeding behavior and food consumption in the goldfish, Carassius auratus, by orexin-A and orexin-B. Brain Research 846 204-209. (https://doi. org/10.1016/S0006-8993(99)02052-1)

Volkoff H, Eykelbosh J \& Peter R 2003 Role of leptin in the control of feeding of goldfish Carassius auratus: interactions with cholecystokinin, neuropeptide $\mathrm{Y}$ and orexin A, and modulation by fasting. Brain Research 972 90-109. (https://doi.org/10.1016/S00068993(03)02507-1)

Volkoff H, Unniappan S \& Kelly SP 2009 The endocrine regulation of food intake. In Fish Neuroendocrinology, pp 421-465. Eds NJ Bernier, GJ Van der Kraak, AP Farrell \& CJ Brauner. Amsterdam: Elsevier.
Volkoff H, Hoskins LJ \& Tuziak SM 2010 Influence of intrinsic signals and environmental cue on the endocrine control of feeding in fish: potential application in aquaculture. General and Comparative Endocrinology 167 352-359. (https://doi.org/10.1016/j. ygcen.2009.09.001)

Volkow ND, Wang GJ \& Baler RD 2011 Reward, dopamine and the control of food intake: implications for obesity. Trends in Cognitive Sciences 15 37-46 (https://doi.org/10.1016/j.tics.2010.11.001)

Waterson MJ \& Horvath TL 2015 Neuronal regulation of energy homeostasis: beyond the hypothalamus and feeding. Cell Metabolism 22 962-970. (https://doi.org/10.1016/j.cmet.2015.09.026)

Wauson E, Zaganjor E, Lee A, Guerra M, Ghosh A, Bookout A, Chambers C, Jivan A, McGlynn K, Hutchison M, et al. 2012 The G protein-coupled taste receptor T1R1/T1R3 regulates mTORC1 and autophagy. Molecular Cell 47 851-862. (https://doi.org/10.1016/j. molcel.2012.08.001)

Wenderlar Bonga S 1997 The stress response in fish. Physiological Reviews 77 591-625. (https://doi.org/10.1152/physrev.1997.77.3.591)

Williams I, Williams KC, Smith DM \& Jones M 2006 Polka-dot grouper, Cromileptes altivelis, can utilize dietary fat efficiently. Aquaculture Nutition 12 379-387. (https://doi. org/10.1111/j.1365-2095.2006.00437.x)

Wilson RP 1986 Protein and amino acid requirements of fishes. Annual Review of Nutrition 6 225-244. (https://doi.org/10.1146/annurev. nu.06.070186.001301)

Wolfson RL \& Sabatini DM 2017 The dawn of the age of amino acid sensors for the mTORC1 pathway. Cell Metabolism 26 301-309. (https://doi.org/10.1016/j.cmet.2017.07.001)

Won ET, Baltzegar DA, Picha ME \& Borski RJ 2012 Cloning and characterization of leptin in a Perciform fish, the striped bass (Morone saxatilis): control of feeding and regulation by nutritional state. General and Comparative Endocrinology 178 98-107. (https://doi. org/10.1016/j.ygcen.2012.04.019)

Wong KKY, Ng SYL, Lee LTO, Ng HKH \& Chow BKC 2011 Orexins and their receptors from fish to mammals: a comparative approach. General and Comparative Endocrinology 171 124-130. (https://doi. org/10.1016/j.ygcen.2011.01.001)

Wootton RJ 1990 Ecology of Teleost Fishes. New York: Chapman and Hall.

Wullimann MF \& Mueller T 2004 Teleostean and mammalian forebrains contrasted: evidence from genes to behavior. Journal of Comparative Neurology 475 143-162. (https://doi.org/10.1002/cne.20183)

Wullimann MF, Rupp B \& Reichert H 1996 Neuroanatomy of Zebrafish Brain: A Topological Atlas. Basel: Birkhaeuser Verlag.

Xu C, Liu WB, Zhang D-D, Cao X-F, Shi H-J \& Li X-F 2018 Interactions between dietary carbohydrate and metformin: implications on energy sensing, insulin signaling pathway, glycolipid metabolism and glucose tolerance in blunt snout bream Megalobrama amblycephala. Aquaculture 483 183-195. (https://doi.org/10.1016/j. aquaculture.2017.10.022)

Yamada T, Katagiri H, Ishigaki Y, Ogihara T, Imai J, Uno K, Hasegawa Y, Gao J, Ishihara H, Niijima A, et al. 2006 Signals from intraabdominal fat modulate insulin and leptin sensitivity through different mechanisms: neuronal involvement in food-intake regulation. Cell Metabolism 3 223-229. (https://doi.org/10.1016/j. cmet.2006.02.001)

Yamamoto T, Nakahata Y, Tanaka M, Yoshida M, Soma H, Shinohara K, Yasuda A, Mamine T \& Takumi T 2005 Acute physical stress elevates mouse period 1 mRNA expression in mouse peripheral tissues via a glucocorticoid-responsive element. Journal of Biological Chemistry 280 42036-42043 (https://doi.org/10.1074/jbc.M509600200)

Yamamoto K, Ruuskanen JO, Wullimann MF \& Vernier P 2011 Differential expression of dopaminergic cell markers in the adult zebrafish forebrain. Journal of Comparative Neurology 519 576-598. (https://doi.org/10.1002/cne.22535)

Yáñez J, Souto Y, Piñeiro L, Folgueira M \& Anadón R 2017 Gustatory and general visceral centers and their connections in the brain of 
adult zebrafish: a carbocyanine dye tract-tracing study. Journal of Comparative Neurology 525 333-362. (https://doi.org/10.1002/ cne.24068)

Zhang C, Forlano PM \& Cone RD 2012 AgRP and POMC neurons are hypophysiotropic and coordinately regulate multiple endocrine axes in a larval teleost. Cell Metabolism 15 256-264. (https://doi. org/10.1016/j.cmet.2011.12.014)
Zhang W, Cline MA \& Gilbert ER 2014 Hypothalamus-adipose tissue crosstalk: neuropeptide $\mathrm{Y}$ and the regulation of energy metabolism. Nutrition and Metabolism 11 27. (https://doi.org/10.1186/1743-707511-27)

Zhou QY \& Palmiter RD 1995 Dopamine-deficient mice are severely hypoactive, adipsic, and aphagic. Cell 83 1197-1209. (https://doi. org/10.1016/0092-8674(95)90145-0)

Received in final form 7 February 2018

Accepted 21 February 2018

Accepted Preprint published online 21 February 2018
(C) 2018 Society for Endocrinology Published by Bioscientifica Ltd. Printed in Great Britain 